\title{
Analyzing Upper Secondary Education Dropout in Latin America through a Cohort Approach
}

\author{
Raja Bentaouet Kattan ${ }^{1} \&$ Miguel Székely ${ }^{2}$ \\ ${ }^{1}$ World Bank Group, Washington, D.C., USA \\ ${ }^{2}$ Center for Education and Social Studies, Mexico City, Mexico \\ Correspondence: Miguel Székely, Center for Education and Social Studies, Mexico City, Mexico. E-mail: \\ mszekely@prodigy.net.mx
}

Received: March 11, 2017

Accepted: April 26, 2017

Online Published: May 15, 2017

doi:10.5539/jel.v6n4p12

URL: http://doi.org/10.5539/jel.v6n4p12

\begin{abstract}
This study examines recent trends and factors in school dropout at the upper secondary education level across Latin America. The methodology employs repeated cross sections of data to track the life cycle path of cohorts of individuals in 18 countries. A key finding is that while upper secondary enrollment rates increased in the region, dropout has remained persistently high, despite relatively favorable macroeconomic conditions. To explain dropout trends, the study examines the impact of three groups of factors: (i) shifts in the cohort size and socioeconomic composition of the population eligible for entering upper secondary; (b) the macroeconomic environment and labor market opportunities; and (c) the returns to schooling. We show that an important factor in persistently high dropout rates has been the higher numbers of students from poor socioeconomic backgrounds reaching upper secondary. In addition, high returns to education have been a pull factor into schooling, while, especially in countries where the majority of youth dropout prior to upper secondary, the data confirm an apparent substitution effect due to the opportunity cost of forgoing employment opportunities. The findings confirm the growing policy focus on upper secondary across Latin America and suggest implications for the policy agenda.
\end{abstract}

Keywords: dropout, dropout rates, education, education policy, household surveys, income effect, public policy, returns to education, secondary education, substitution effect

\section{Introduction}

Across Latin America (LA), the greatest dropout rates in education systems occur at Upper Secondary Education (USE). Around one in every three youth in the region do not reach this level at all, and about 45 percent of those that enter USE do not graduate (Székely \& Karver, 2014). While policy makers prioritized expanding coverage of primary and Lower Secondary (LS) schooling during most of the $20^{\text {th }}$ century, they are now turning to USE, where low enrollment, retention and graduation rates are growing concerns. Along with the issue of low basic education quality, this seems to be the region's major educational challenge at the outset of the $21^{\text {st }}$ century (Note 1).

Having large numbers of adolescents out of school has important consequences. Early dropout limits the skill sets of new generations entering the work force, which affects both a country's current productivity levels and future capacity for facing later phases of the demographic transition when dependency rates rise. In addition, USE age adolescents are exposed to a series of risks that are more difficult to address when populations are out of school (Note 2). Furthermore, during adolescence an individual's personality aspects (including planning, and organizational and decision making capabilities, among others) are still developing, so exiting the school environment prematurely can hinder the process (Note 3).

Despite its importance, the literature on the causes behind LA's relatively low enrollment and high USE level dropout is scarce (Note 4). The literature often looks either at regional dropout trends but not causes, or delves into the causes within a single country (Note 5). This paper seeks to help fill this gap. In particular, this study analyzes why, despite a recent favorable macroeconomic environment-characterized by high real Gross Domestic Product (GDP) growth rates, significant declines in poverty, and reductions in income inequality — the 
proportion of youth exiting school during USE age remains high, and seems to have become a "bottleneck" for further education expansion in LA (Note 6).

Specifically, we explore the influence of three potential explanatory factors for the region's persistently high USE dropout rates: i) the socioeconomic composition of the population eligible for entering USE, ii) the macroeconomic environment, particularly employment opportunities for youth entering working age, and iii) returns to schooling (which reflect the labor market's value of different education levels and are also a proxy for education relevance).

The methodological approach used is to construct a synthetic panel from 234 cross sections of household survey data, from which we follow schooling trajectories of different generations of individuals observed at different points in time. These trajectories are then related to the conditions characterizing the environment during the time when school enrollment decisions were being taken. The cohort approach allows us to follow life-cycle trajectories that relate more closely to the dynamic decisions of households and individuals regarding schooling, work and/or other activities.

The paper is divided into the following five sections. Section 2 presents the data and cohort methodology used and the main stylized facts of USE dropout in the region. Section 3 examines our findings on patterns of attendance and dropout across countries. Section 4 describes the three groups of potential influencing factors examined in the study and Section 5 presents the results of econometric estimates of the relation between these factors and USE dropout. Section 6 concludes.

\section{Data and Stylized Facts}

\subsection{Data and Approach}

Several studies have documented the low attendance and graduation levels for USE in LA. The most recent of these agree that on average around the year 2010, between 64 and 68 percent of USE age adolescents attended school in the region's countries, and graduation rates from this level reached between 45 and 48 percent (Note 7). These USE completion rates are well below the OECD's average of 84 percent in 2009 (see OECD, 2011).

USE attendance rates are clearly related to household and individual decisions made at USE ages, but are also a consequence of early life events that influence the probabilities of LS completion and of accessing and completing USE (Note 8). This implies that it is necessary to go beyond a snapshot-or even a series of snapshots taken at a certain age- to more comprehensively and dynamically view schooling trajectories. To do so empirically, having panel data following specific individuals at various stages of their life cycle would be ideal. Unfortunately, these kinds of data are not widely available in LA (Note 9).

An alternative approach in the life cycle choice literature has been to use repeated cross sections of data - typically from household surveys - to track the life cycle path of representative groups of individuals belonging to a birth cohort (Note 10). As noted by Verbeek (2007), the main limitation of these types of data is that they follow groups of representative individuals rather than the same individual over time. As such, when high variability is observed, the cohort average will reflect individual cases to a lower extent. This is of less concern when the within cohort variance of the variable under analysis is low. Two advantages of using repeated cross sections, however, are that they minimize attrition biases and problems of non-response that are common in true panels, and when surveys are nationally representative averaging across cohorts likely reduces idiosyncratic measurement error and heterogeneity (Attanasio \& Banks, 1998).

Repeated cross sections were selected as an adequate empirical option for the present study, since in LA enough household surveys covering long time spans are available to allow us to follow a cohort from when it enters primary (ages 5-6), until its exit from USE (around age 18). These surveys provide information on each generation's schooling history as well as the extent of USE dropout (Note 11). Furthermore, as opposed to official education administrative records, such surveys include those who have left the education system. Finally, having enough cross sections (as is our case), permits statistical and econometric analysis of the relation between various factors and the variables of interest, as in Section 5.

We construct our data set using micro data from 234 cross sections available for 18 LA countries spanning from 1980 to 2012, from which schooling indicators representative of more than 96 percent of the population of the region can be constructed (See Appendix Table A.1 for the number of surveys and years available for each country). The surveys are representative of each country's total population, with the exception of Argentina and Bolivia for surveys prior to the 2000s and Uruguay, where the samples are for urban areas only. 
Since each country uses different years, formats, computing codes, questionnaires and definitions, we standardize relevant indicators and produce a comparable data set within countries, and across countries and years. Our homogenization process considers each country's different age requirements for attending each education level and we follow UNESCO's ICSED 1997 classification, when available (Note 12). Most countries organize their education system in five levels: pre-primary, primary, LS, USE, and HE-some countries like Peru do not distinguish between lower and upper secondary.

We find that the greatest variety in arrangements is precisely for USE (See Appendix Table A.2). Official USE attendance ages are from 15 to 17 in 9 of the 18 countries analyzed, with a typical duration of 3 years and early graduation options in some cases. In Colombia and Peru, entry is also at age 15, but with a shorter duration of 2 years. In Bolivia, Chile, and the Dominican Republic USE lasts 3 years, but has an earlier entry (age 14). The oldest entry ages are at 16, with duration of 2-3 years. Uniquely, in Brazil USE starts at age 15 but lasts 4 years. Through our standardization process we adjust the information to define the age at which adolescents are expected to be enrolled in USE.

The micro data also permit us to address how enrollment and graduation rates are defined. As illustrated by Heckman and Laffontaine (2007) and Murane (2013), these variables can vary considerably. For our purposes, we are able to be totally explicit about the different definitions that are used and use only those that are comparable across countries and over time.

\subsection{General Stylized Facts Emerging from the Data}

Our synthetic panel illustrates the average evolution of school enrollment patterns for four different generations over time in LA (Figure 1). The 15 years spanned include USE age entrants around 1995 to entrants around 2010 (Note 13). Some youth are shown during their full schooling trajectory (in the middle two lines), while others are observed during the first or last segments. Our dynamic analytical approach follows the same group of individuals over time, rather than snapshots of different generations observed only at a particular age, as in other studies.

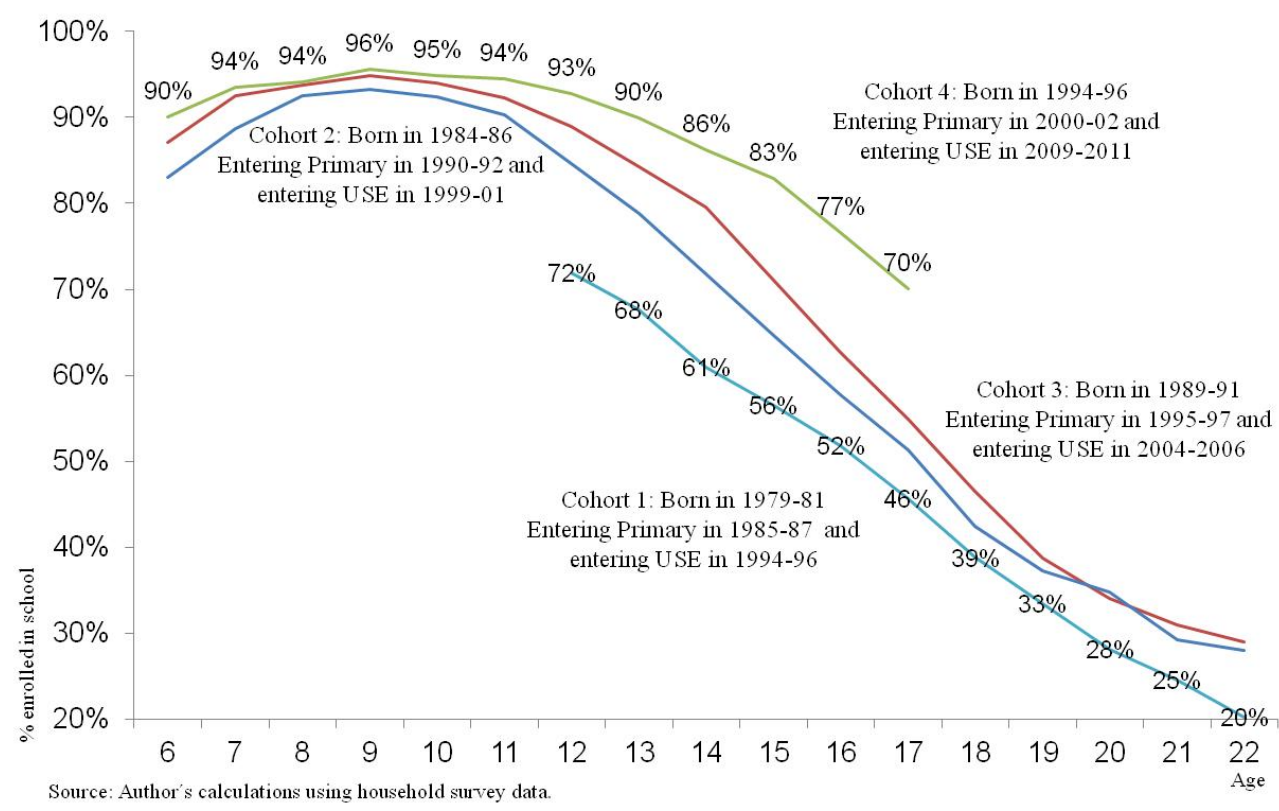

Figure 1. Evolution of schooling enrollment of four LA cohorts between 1990 and 2010

The first generation included (Cohort 1), was born between 1979 and 1981 and reached primary age around 1985-1987 and average USE age between 1994 and 1996. Cohort 2 is observed at USE age 5 years later between 1999 and 2001, while Cohorts 3 and 4 are observed also at 5 year intervals at USE age during 2004-2006 and 2009-2011, respectively.

The data illustrate that 56 percent of individuals in Cohort 1 were enrolled in school at age 15, versus 83 percent for Cohort 4 . This shows that a higher proportion of youth remain in school at USE entry age in LA during the 
2010s as compared to generations entering this age around 1995. In addition, 70 percent of Cohort 4 remains in school at USE exit (age 17), considerably higher than the 46 percent for Cohort 1 . This reveals a considerable expansion in education coverage for adolescents across the region during these years.

When comparing transitions from LS to USE, however, the panel approach, which offers an additional view on each cohort's dynamics (equivalent to the slope of each curve), reveals little progress. Here we compare the exit rate from schooling across different ages for each generation. For Cohort 1, the percent still in school is 72 percent at LS entry (12-13 years of age), and drops to 46 percent at the USE exit age of 17-a decline of 26 percentage points. For Cohort 4, this same drop is from 93 percent to 70 percent, implying a reduction of 23 points, similar to the decline for Cohort 1 . The difference is that a significantly higher proportion of youth remain in school at age 12-with an increase of practically 20 percentage points in attendance rates. Therefore, we find little progress in reducing drop out during the years under analysis - in both cases, practically 1 out of every 4 youth drop out between LS entry and USE exit age. Comparison with Cohorts 2 and 3 is also of interest and suggests that while USE enrollment rates increased between the mid-1990s and 2000, USE dropout rates also increased during this period.

The focus of the present analysis is precisely on examining why, in spite of the increased enrollment, dropout rates from the schooling system remain between 23 and 26 percentage points when individuals transition from LS to USE, and during USE. More precisely, the objective is to understand why dropout rates at USE age actually increase. Between Cohorts 1 and 4 we find that the dropout rate between ages 12 and 14 declines by 11 and 7 points, respectively; dropout during the transition from LS exit to USE entry is reduced from 5 to 3 points between Cohorts 1 and 4; but the dropout rate between ages 15 and 17 increases from 10 to 13 points between cohorts (Figure 1).

Figure 2 presents the average enrollment rates for individuals at USE age. While the increase in total enrollment is still apparent, there is a considerable share of USE aged youth enrolled in LS or primary throughout the period. Additionally, only a small decline in such attendance from 27 to 25 percent is observed from Cohort 1 to Cohort 4. The persistently high over-age rates might be one of the factors behind the considerable drop out observed.

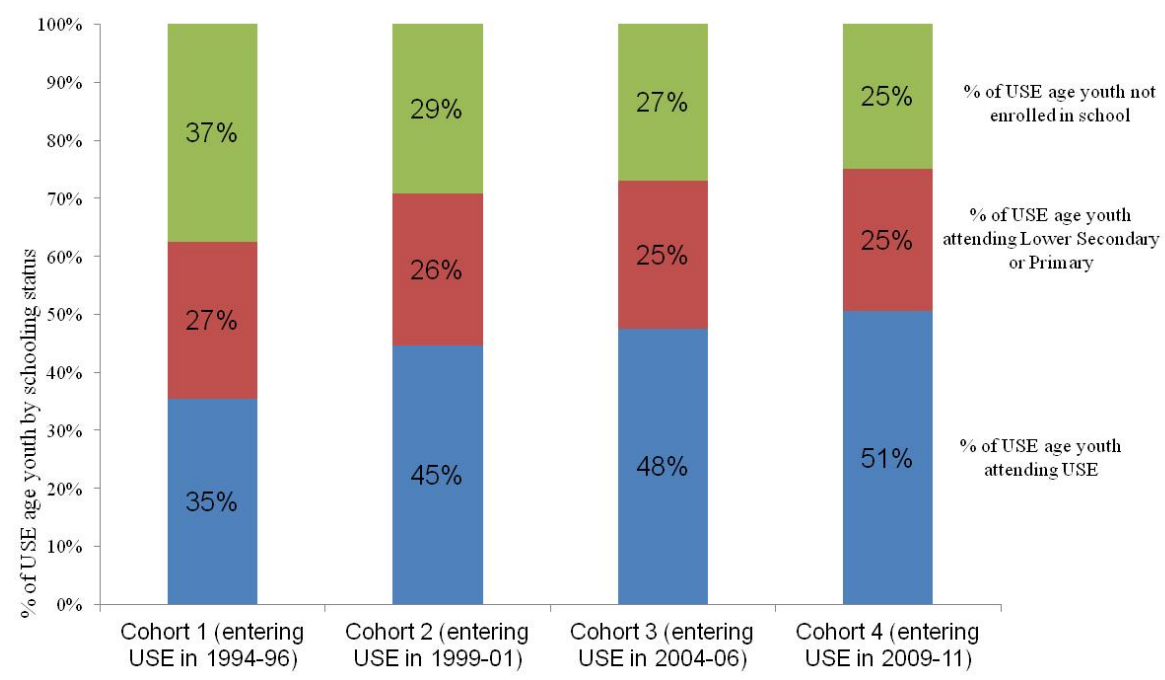

Figure 2. Distribution of USE age youth by schooling status for cohorts entering USE in the 1990s, 2000s and 2010s in LA

Examining trajectories by gender we find that while females' school enrollment rates were below those observed for males at ages 12 to 17 for Cohort 1, in the case of Cohort 4, this is reversed (Figure 3). This finding is consistent with the expansion of education coverage for females in most LA countries since the end of the 1990s. As in the case of the overall population, the most salient feature is that the slope of the curves after age 12 remains similar for both cohorts for both genders, confirming persistently high dropout rates at USE ages during the course of 15 years. The results show slight decreases in dropout rates during LS ages and at the transition between LS and USE ages, as in Figure 1, but the small increases in drop out at USE cancel them out. 

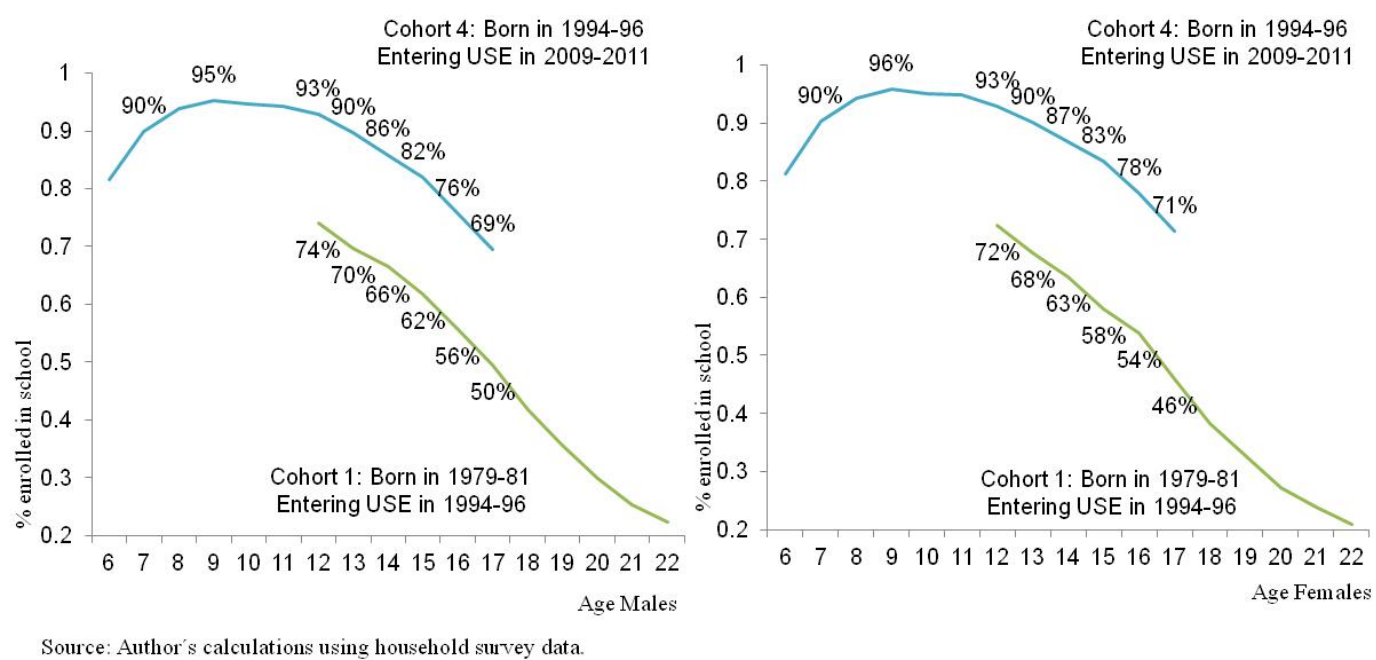

Figure 3. Evolution of schooling enrollment of two LA cohorts of males and females between 1990 and 2010

\subsection{Age, Cohort and Time Effects for Secondary School Enrollment}

We construct 144 cohort trajectories for the 18 countries included in our data base, and each cohort is observed at different lengths during different years (depending on the surveys available). Our data base includes observations starting in 1980. The oldest cohorts for whom a full school age trajectory can be followed are born in 1974-1976 and can be observed until they are about 34 to 36 years old. Cohorts born during the 9 previous years are observed first in 1980 when they are already of late primary or LS age and we can trace their education choices from the ages of 15-17 onwards (Note 14). The youngest cohorts in our analysis are born between 1994 and 1996 and were expected to enter primary during 2000-2002. We can follow them up to the age of expected USE attendance, around 9 years later. The cohort trajectories constructed with our data reveal that school enrollment rates decline fastest in a critical period between ages 15 and 20, where attendance rates drop from around 80 to 40 percent (Figure 4 ).

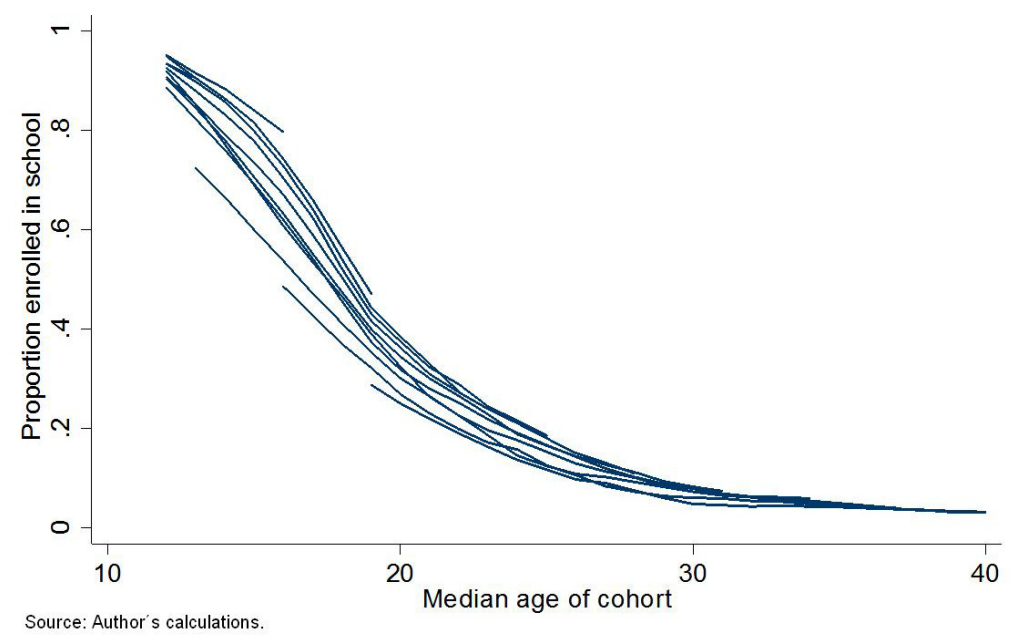

Figure 4. Proportion enrolled in school by age \& cohort, all cohorts for LA (1985-2012)

Figure 4 reveals several sources of variation. The first is "cohort effects", which reflect different structural conditions for different generations. For the cohorts that start being observed around age 12, generations show significantly lower attendance levels of around 70 percent compared to the group with the highest rates of about 
90 percent. The change in attendance levels between the school attendance trajectories in Cohorts 1-4 would belong to these types of effects, which tend to apply to all individuals in one cohort as compared to another (Figures 1 and 3).

The second is variations along the life cycle of each cohort. The declining trend in school attendance that is observed as all cohorts age is normally classified as an "age effect". The inverted " $u$ " shape patterns in school attendance observed are a good illustration of this.

A third source of variation is "time effects", which correspond to shocks that can affect school attendance choices irrespective of an individual's age or cohort. An economic crisis or natural disaster that alters the expected age pattern of school attendance for all cohorts in a country would be examples. These effects, however, are not immediately apparent in our data.

Several authors have attempted to identify the aforementioned age, cohort, and time effects separately for analysis of saving over the life cycle (Note 15). Following Székely and Karver (2014), we adapt this approach to identify patterns of time-use choices, and in particular, school attendance trajectories among youth. Estimating these effects is simpler than in the case of household savings since the indicators are binary rather than continuous, and they follow a different (and less complex) underlying investment model. For example, while savings may fluctuate greatly throughout the life cycle, the decision of when to leave school usually occurs before age 25 (Note 16).

Age, cohort and time effects for school enrollment at the regional level are examined in Figure 5. Estimated age effects show a steep life cycle trajectory of decline in school attendance between ages 12 and 20 (Panel A). Cohort effects show a positive trend, with each cohort of youth achieving on average higher levels of enrollment than their predecessors (Panel B). Overall time effects were found to have a value of zero (Panel C).

Panel A

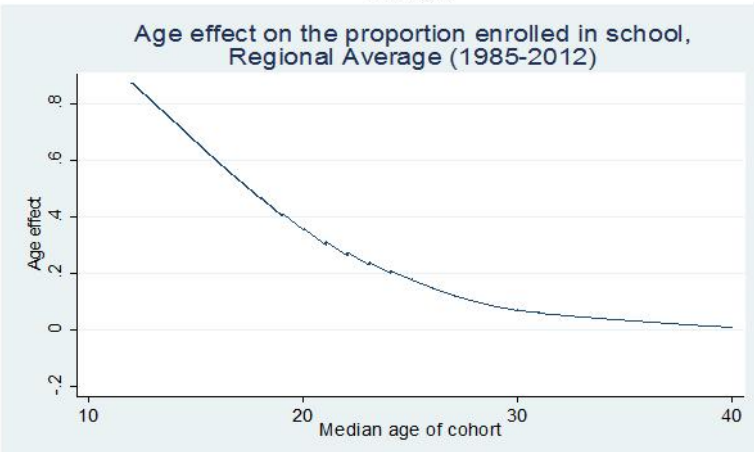

Panel B

Cohort effect on the proportion enrolled in school, Regional Average (1985-2012)

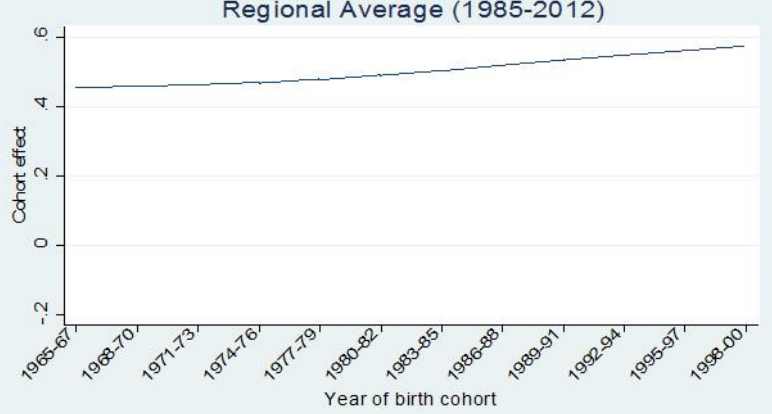

Time effect on the proportion enrolled in school,

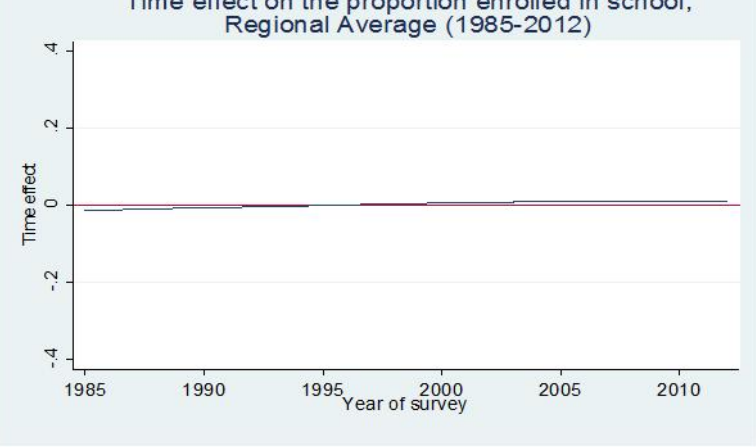

Source: Author's calculations.

Figure 5. Estimated age, cohort and time effects for school enrollment in LA 


\section{Patterns of Attendance and Dropout}

\subsection{Magnitudes of School Dropout}

To compare the evolution during the 2000s, we focus on individuals in Cohort 2 that were at USE age around the years 1999-2001 and Cohort 4 that were at USE age by 2009-2011 (See Appendix Tables A.3 and A.4). For each country, we identify the official entry and exit ages for LS and USE in order to make relevant comparisons. Table 1 summarizes the changes in enrollment for each country.

Table 1. Changes in dropout rates between Cohort 2 (entered USE age during 1999-2001) and Cohort 4 (entered USE age in 2009-2011)

\begin{tabular}{|c|c|c|c|c|c|c|c|c|c|}
\hline \multirow[t]{2}{*}{ Country } & \multicolumn{3}{|c|}{$\%$ Dropout during LS Age } & \multicolumn{3}{|c|}{$\%$ Dropout during USE Age } & \multicolumn{3}{|c|}{ \% Dropout btwn LS entry \& USE exi } \\
\hline & Cohort 2 & Cohort 4 & Change & Cohort 2 & Cohort 4 & Change & Cohort 2 & Cohort 4 & Change \\
\hline Argentina & $14 \%$ & $9 \%$ & $-6 \%$ & $13 \%$ & $14 \%$ & $1 \%$ & $27 \%$ & $23 \%$ & $-4 \%$ \\
\hline Bolivia & $6 \%$ & $11 \%$ & $4 \%$ & $17 \%$ & $17 \%$ & $0 \%$ & $24 \%$ & $28 \%$ & $4 \%$ \\
\hline Brasil & $13 \%$ & $7 \%$ & $-6 \%$ & $27 \%$ & $31 \%$ & $4 \%$ & $41 \%$ & $38 \%$ & $-3 \%$ \\
\hline Chile & $7 \%$ & $1 \%$ & $-5 \%$ & $26 \%$ & $5 \%$ & $-22 \%$ & $33 \%$ & $6 \%$ & $-27 \%$ \\
\hline Colombia & $24 \%$ & $10 \%$ & $-14 \%$ & $12 \%$ & $8 \%$ & $-4 \%$ & $35 \%$ & $18 \%$ & $-17 \%$ \\
\hline Costa Rica & $28 \%$ & $10 \%$ & $-18 \%$ & $10 \%$ & $10 \%$ & $0 \%$ & $38 \%$ & $19 \%$ & $-18 \%$ \\
\hline Dominican R. & $11 \%$ & $6 \%$ & $-5 \%$ & $18 \%$ & $9 \%$ & $-8 \%$ & $28 \%$ & $15 \%$ & $-13 \%$ \\
\hline Ecuador & $24 \%$ & $13 \%$ & $-11 \%$ & $18 \%$ & $28 \%$ & $10 \%$ & $41 \%$ & $41 \%$ & $-1 \%$ \\
\hline Guatemala & $26 \%$ & $23 \%$ & $-4 \%$ & $7 \%$ & $18 \%$ & $11 \%$ & $33 \%$ & $41 \%$ & $8 \%$ \\
\hline Honduras & $32 \%$ & $26 \%$ & $-6 \%$ & $9 \%$ & $15 \%$ & $6 \%$ & $41 \%$ & $41 \%$ & $0 \%$ \\
\hline México & $31 \%$ & $21 \%$ & $-11 \%$ & $10 \%$ & $18 \%$ & $8 \%$ & $41 \%$ & $39 \%$ & $-2 \%$ \\
\hline Nicaragua & $20 \%$ & $14 \%$ & $-6 \%$ & $12 \%$ & $19 \%$ & $7 \%$ & $32 \%$ & $32 \%$ & $1 \%$ \\
\hline Panamá & $7 \%$ & $3 \%$ & $-4 \%$ & $7 \%$ & $8 \%$ & $1 \%$ & $14 \%$ & $12 \%$ & $-2 \%$ \\
\hline Perú & $26 \%$ & $16 \%$ & $-10 \%$ & $1 \%$ & $8 \%$ & $7 \%$ & $27 \%$ & $24 \%$ & $-3 \%$ \\
\hline Paraguay & $21 \%$ & $4 \%$ & $-17 \%$ & $27 \%$ & $23 \%$ & $-4 \%$ & $48 \%$ & $27 \%$ & $-21 \%$ \\
\hline El Salvador & $21 \%$ & $14 \%$ & $-7 \%$ & $19 \%$ & $15 \%$ & $-4 \%$ & $40 \%$ & $29 \%$ & $-11 \%$ \\
\hline Uruguay & $20 \%$ & $14 \%$ & $-7 \%$ & $16 \%$ & $19 \%$ & $3 \%$ & $37 \%$ & $32 \%$ & $-4 \%$ \\
\hline Venezuela & $25 \%$ & $11 \%$ & $-15 \%$ & $21 \%$ & $14 \%$ & $-7 \%$ & $46 \%$ & $24 \%$ & $-22 \%$ \\
\hline Average & $20 \%$ & $12 \%$ & $-8 \%$ & $15 \%$ & $15 \%$ & $0 \%$ & $35 \%$ & $27 \%$ & $-8 \%$ \\
\hline
\end{tabular}

Source: Author's calculations from household survey data.

In the case of LS age, with the exception of Bolivia, there is an important decline in school dropout across the region between Cohorts 2 and 4 (Table 1, columns 1 to 3). On average, for the region as a whole, dropout at LS ages declines by 8 points during this period. However, in the case of school attendance during USE age the opposite pattern is observed (Table 1, columns 4 to 6 ).

For a majority of countries in the region dropout at USE age increased, and in only 3 out of 18 is there a significant reduction. This is the main stylized fact to be explored in the following sections, and is of even greater interest in light of the positive macroeconomic environment observed during these years.

Columns 7-10 in the Table summarize dropout rates for the full secondary cycle. The main result is that in all countries, except Guatemala, the decline in dropout at LS cancels out the increase during USE, resulting in lower dropout rates overall. At the regional level, the reduction by 8 points at LS age, combined with no change for USE age, results in an overall 8 percent decline. 


\subsection{Patterns of Dropout across LA}

The information on school trajectories can be used to verify the point at which dropout takes place by comparing school attendance for each cohort observed at different ages (See Appendix Tables A.3 and A.4). This is of interest since the policy approach for increasing school attendance in countries where youth leave school more prematurely is not necessarily the same as that for addressing school exit at later stages.

Our main finding is that the relative importance of dropout during LS age declined from 38 to 25 percent during the 2000s, while the relative share of USE age dropout increased from 43 to 58 percent - dropout in transition between LS and USE remained fairly stable between 17 and 19 percent. This confirms recent concerns about the USE level throughout the region (Table 2).

Table 2. Proportion of dropout that occurs at different segments of schooling trajectories in LA (Cohort 4 going through USE age in 2009-2011)

\begin{tabular}{|c|c|c|c|}
\hline Country & $\%$ of Dropout during LS & $\begin{array}{c}\% \text { of Dropout in transition from } \\
\text { LS to USE }\end{array}$ & $\%$ of Dropout during USE \\
\hline Honduras & $45 \%$ & $18 \%$ & $37 \%$ \\
\hline Colombia & $41 \%$ & $16 \%$ & $43 \%$ \\
\hline Peru & $39 \%$ & $27 \%$ & $34 \%$ \\
\hline Guatemala & $36 \%$ & $20 \%$ & $44 \%$ \\
\hline Nicaragua & $33 \%$ & $9 \%$ & $58 \%$ \\
\hline Costa Rica & $32 \%$ & $18 \%$ & $50 \%$ \\
\hline Bolivia & $5 \%$ & $34 \%$ & $61 \%$ \\
\hline El Salvador & $23 \%$ & $26 \%$ & $51 \%$ \\
\hline Venezuela & $19 \%$ & $25 \%$ & $56 \%$ \\
\hline Mexico & $29 \%$ & $24 \%$ & $47 \%$ \\
\hline Paraguay & $0 \%$ & $15 \%$ & $85 \%$ \\
\hline Brasil & $10 \%$ & $8 \%$ & $82 \%$ \\
\hline Chile & $21 \%$ & $3 \%$ & $76 \%$ \\
\hline Panama & $14 \%$ & $15 \%$ & $71 \%$ \\
\hline Ecuador & $21 \%$ & $11 \%$ & $68 \%$ \\
\hline Dominican R. & $26 \%$ & $12 \%$ & $62 \%$ \\
\hline Argentina & $22 \%$ & $16 \%$ & $61 \%$ \\
\hline Uruguay & $27 \%$ & $15 \%$ & $58 \%$ \\
\hline LAC average Cohort 4 & $25 \%$ & $17 \%$ & $58 \%$ \\
\hline LAC average Cohort 2 & $38 \%$ & $19 \%$ & $43 \%$ \\
\hline
\end{tabular}

Source: Author's calculations from household survey data.

Using these differences as reference we divide countries into three groups by using data from Cohort 4 (cutoffs are set by identifying concentrations of countries around similar patterns). A similar pattern emerges when using Cohort 3.

Honduras, Colombia, Peru, Guatemala, Nicaragua and Costa Rica are classified as countries with early dropout, since they present the largest shares of individuals that exit school during LS ages (reaching levels between 32 and 45 percent), while relatively lower proportions of all dropout occurs during USE age. Bolivia, El Salvador, Venezuela and Mexico are classified as countries with significant dropout in transition from LS to USE ages. In these cases, a typically high proportions of between one fourth and one third of all dropout occurs as individuals evolve from LS exit age to USE entry age-Peru also shows high proportions of dropout in transition, however, the proportion observed in the LS stage is even greater so it is classified as "early dropout". Finally, the 
remaining countries, where most of the dropout rate is observed during USE age, are classified as late dropout. In these countries on average 70 percent of those exiting school do so at USE age.

By examining cohort trajectories using these classifications, several interesting comparisons emerge (Figure 6) with respect to: (i) Age effects (Panel A): countries with early dropout generally have the lowest attendance rates at all ages, followed by those classified as having high shares of dropout in transition. Additionally, higher proportions remain in school to around age 25 in the late drop out group. (ii) Cohort effects (Panel B): there is a more pronounced positive trend for countries in the early dropout group, especially for cohorts born around 1985 , and for countries with high shares of dropout in transition. For late dropout countries, cohort effects are much more modest, which suggests a generational convergence in school enrollment across the region. (iii) Time effects, while at the regional level these effects are not apparent (Figure 5) for the early dropout countries, there is an important negative time effect in years before 2000 (Figure 6, Panel C). In general these countries register lower incomes, so negative macroeconomic conditions such as those during the late 1980s and 1990s could lead to pressing demands to reallocate resources to short term priorities, and away from longer-term investments in human capital and schooling.

Panel A

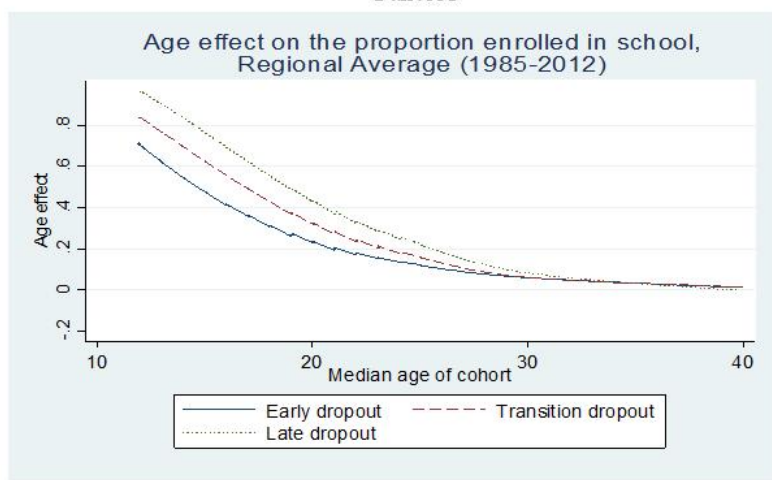

Panel B

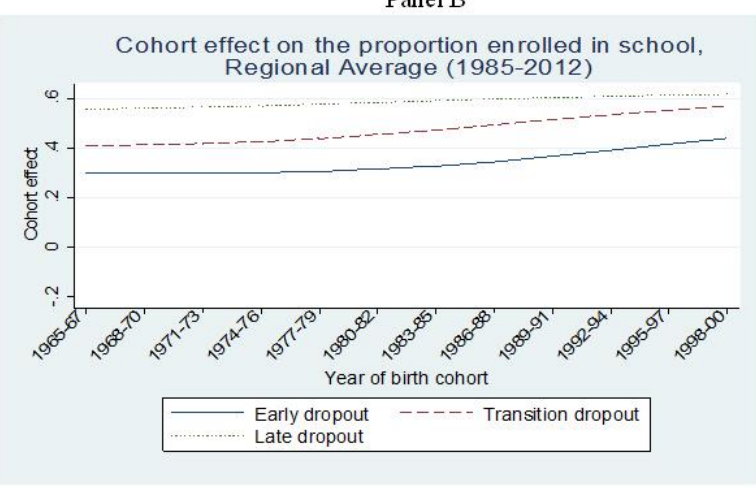

Time effect on the proportion enrolled in school, Regional Average (1985-2012)

Panel C

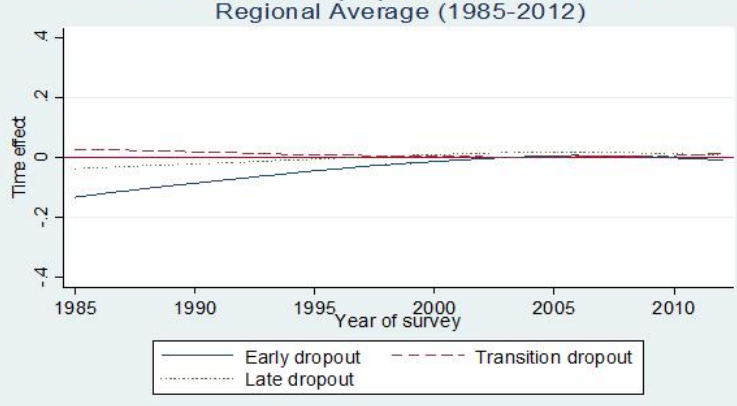

Source: Author's calculations.

Figure 6. Estimated age, cohort and time effects for school enrollment in LA, by groups of countries

\section{Factors Associated with School Dropout}

Most of the discussion on the economic determinants of school enrollment has evolved around the human capital investment framework developed by Becker (1975) (Note 17). Within this framework schooling (and other human capital) investments are made until the private marginal benefit - which depends on the expected private gains (e.g., in wages/salaries in labor markets, employment possibilities, access to higher quality jobs) - of the investment equals its private marginal costs, which include both the resources required for accessing the service (including transport, materials, tuition, etc.) and the opportunity cost of the time in school (Note 18).

In the presence of credit constraints and imperfect insurance markets the investment decision will be restricted by family preferences, characteristics, current resources, and endowments through at least two channels. One is a direct effect that acts through limiting and making access to the resources needed for financing the private costs of schooling more costly, which implies that the poorer the household, the lower the investment in the human capital of its members even in the presence of high potential returns. Another includes indirect mechanisms that 
alter the marginal costs and benefits, such as higher levels of risk aversion, scarcer information on labor market opportunities and schooling returns, insufficient coping mechanisms for unexpected shocks, and even higher discount rates, that characterize lower income households (Note 19). Additionally, family characteristics, resources and endowments will interact with the household's external environment to determine the final outcome in terms of schooling investments.

The present study focuses on verifying the influence of three groups of variables that could help explain the increase in dropout at USE attendance age in the region. We examine the evolution of: i) cohort size and cohort composition, ii) income and labor market conditions, and iii) returns to schooling in the region.

\subsection{Cohort Size and Composition}

First, we verify the extent to which increased primary and LS graduation rates and the influx of previously excluded low income groups generate demand pressures that current USE systems have not been able to adequately absorb (Note 20). If the poor are more prone to drop out from school, their increase as a share of new entrants into USE could translate into higher dropout in those countries showing late drop out. In addition, the demographic shift that most LA countries have experienced since the 1990s has generated the largest numbers of youth of USE age ever observed, although with decreasing trends in recent years (Note 21).

An important shift is the composition of the population in the schooling system. If income and human capital investment are positively correlated, increases in the population attending school will most likely result in the entry of the lower income groups previously excluded. The composition effect influences overall school dropout rates by increasing the proportion of youth that are exposed to risks related to adolescence and unexpected income shocks, and that live in households with fewer means to address them. Furthermore, as explained by Murane (2013), lower incomes are usually associated with higher rates of time preference, and therefore, lower incentives to invest in longer term ventures such as the accumulation of human capital.

\subsection{Income and Labor Market Conditions}

As for the macroeconomic environment, at least two aspects are likely to influence school attendance decisions at USE ages, including the greater income growth rates and higher economic stability during the 2000 s. On one hand, higher income and wage levels would be expected to increase household resources for investing in human capital, leading to greater school enrollment (a positive income effect). On the other, the same factor can generate incentives for leaving school before completing USE by increasing the opportunity cost for youth of staying in school (a substitution effect).

Furthermore, if households are risk adverse and find restrictions to insure, greater uncertainty reduces their private marginal benefits in utility terms. When physical capital assets can be used as a buffer, individuals may be able to protect long-term investments in schooling. But in their absence, the reallocation of household resources may lead to reduced schooling investment. These reductions or interruptions in schooling affect subsequent attainment, because as a child ages the opportunity cost of not working generally increases. As such, even temporary shocks can have long lasting effects. Also, children behind their peers in grade achievement may become discouraged and drop out, and high transaction costs of entering and exiting schooling may preclude or delay re-entry of dropouts. Therefore, the more stable macro environment would be expected to positively affect school enrollment (Note 22).

With respect to the labor market, there are at least two direct channels through which conditions could influence school enrollment decisions. First, relevant wage levels can cause two types of reactions: i) if the reference wage for USE age youth -the wages to which close age groups have access- increases, so do the opportunity costs of remaining in school and incentives for substituting school time for paid work (negatively affecting school attendance), and ii) higher wages also imply greater household resources, which have a positive income effect on enrollment. The size of both effects in the same household will depend on characteristics and preferences shaped by socioeconomic status, cultural patterns, and expected probabilities of graduation (Note 23). Second, the probability of accessing the prevalent market wage will depend on employment opportunities. In a tight labor market with high unemployment and low employment generation, the opportunity cost of remaining in school will be lower, leading to smaller substitution and income effects. Similarly, more stable or higher quality jobs will increase the opportunity cost of remaining in school, but can also make income effects stronger, with an ambiguous final effect. 


\subsection{Returns to Schooling}

Related to the macroeconomic and labor market conditions, a factor that is expected to affect household schooling investment decisions through its effects over the opportunity cost of time, is the returns to education, which are normally regarded as a measure of the extent to which the labor market values different types of skills at different times (Note 24). We expect here that higher perceived long-term returns would be associated with higher school enrollment rates, and vice versa.

It is important to stress, however, that returns to education do not only reflect school quality but also depend on context. In particular, factor endowments determine production structures and therefore the demand for different skill types, which can alter the returns to education and the incentives to invest in it. Substantial natural resources, for example, are thought to lead to production structures in which returns to broad education are limited, while the returns to some forms of specialized technical education (e.g., mining, engineering) may be high. Furthermore, as noted by Spilimbergo, Londoño and Székely (1999), the rewards to education are also affected by the extent of a country's exposure to international trade. For example, trade openness, which generally involves more rapid changes in technology and capital, may have positive effects on education returns and incentives to acquire education (Rosenzweig, 1990; Foster \& Rosenzweig, 2004).

\section{Relevance of the Different Factors}

This section presents our findings on the different forces discussed in the prior section. To empirically explore the magnitude and direction of these forces, we exploit the same synthetic panel of household survey data, from which we follow cohort trajectories over time and link them (?) with data on variables representing the environment in which school enrollment decisions were made.

We start from the basic idea that the relation between the share of youth enrolled in school and the factors that determine it can be expressed as:

$$
Y_{c j t}=f\left(D_{j t}, M_{j t}, L_{j t}, R_{j t}\right)
$$

where $\mathrm{Y}$ represents the outcome of interest for each cohort $\mathrm{c}$ in country $\mathrm{j}$ at time $\mathrm{t}$ (the proportion of enrolled youth), which is a function of demographic (D), macroeconomic (M), labor market (L) factors and of the returns to schooling (R). Equation (1) can be modified as a function of lagged variables, so our estimation is:

$$
Y_{\mathrm{cjt}}=\alpha_{0}+\beta_{1} D_{\mathrm{jt}}+\beta_{2} \mathrm{M}_{\mathrm{jt}}+\beta_{3} \mathrm{~L}_{\mathrm{jt}}+\beta_{4} \mathrm{R}_{\mathrm{jt}}+\varepsilon_{\mathrm{cjt}}
$$

where for notational simplification $\beta_{\mathrm{i}}$ represents kx1 parameters of interest, and $D_{j t}, M_{j t}, L_{j t}$ and $R_{j t}$ represent vectors of demographic, macroeconomic, labor market, and education returns at the country-year level, respectively, and $\varepsilon$ is the error term with $\mathrm{E}\left(\varepsilon_{\mathrm{cjt}} \mid \mathrm{D}_{\mathrm{jt}}, \mathrm{M}_{\mathrm{jt}}, \mathrm{L}_{\mathrm{jt}}, \mathrm{R}_{\mathrm{jt}}\right)=\mathrm{E}\left(\varepsilon_{\mathrm{cjt}}\right)=0$.

Since our interest is in identifying the variables associated with changes in school enrollment (E) decisions along the life cycle, the outcome of interest is:

$$
\Delta \mathrm{E}_{\mathrm{cjt}}=\mathrm{E}_{\mathrm{cjt}}-\mathrm{E}_{\mathrm{c}-1, \mathrm{j}, \mathrm{t}-1}
$$

That is, our dependent variable is equal to the absolute change in the proportion of youth enrolled in cohort $\mathrm{c}$ in time $t$ compared to the proportion in the same cohort at the previous age bracket in $t-1$, so:

$$
\Delta \mathrm{E}_{\mathrm{ct}}=\alpha_{0}+\beta_{1} \Delta \mathrm{D}_{\mathrm{jt}}+\beta_{2} \Delta \mathrm{M}_{\mathrm{jt}}+\beta_{3} \Delta \mathrm{L}_{\mathrm{jt}}+\beta_{4} \Delta \mathrm{R}_{\mathrm{jt}}+\varepsilon_{\mathrm{cjt}}
$$

where $\Delta$ presents the absolute change and $\Delta \mathrm{D}_{\mathrm{jt}}=\mathrm{D}_{\mathrm{jt}}-\mathrm{D}_{\mathrm{j}, \mathrm{t}}$ and so on. Specifically, for all variables we follow each cohort in its transit from USE entry to USE exit ages in each country. The typical pattern corresponds to cohorts evolving from the 12-14 to the 15-17 age bracket, although the specific ages are adjusted to match each country's official ages. This allows similar examinations of the school enrollment dynamics for each cohort as it occurs along the life cycle.

To verify the influence of demographic, macroeconomic, labor market factors and schooling returns over the share of individuals in a given cohort dropping out of school at critical ages, we estimate equation (4) by pooling all cohort trajectories for all countries and survey years in our data base. The dependent variable is the change in the share of individuals enrolled in school in each cohort at each spell-depending on the country and survey year - and is linked with a series of independent variables obtained from different sources for the same period.

To account for differences in cohort sizes over time, we consider the fertility rate at each cohort's year of birth. To account for cohort composition effects we compute the proportion of individuals in the lower 40 percent of the income distribution that attended LS at the official LS age in each cohort. To avoid endogeneity with the dependent variable - which includes the same cohort of reference in its measurement-we instrument this variable by using the lagged value of the same variable, which refers to an earlier cohort. For the macroeconomic 
environment, we use the growth rate of GDP per capita and the inflation rate, from the World Development Indicators.

The rest of the variables are obtained directly from our household survey database. To characterize labor market dynamics we compute the average wage and the proportion of individuals that are employed under a remunerated activity, for individuals in the $25-45$ age brackets in each country and year. These age groups are above the USE ages considered in the dependent variable and so can be considered as exogenous. Returns to schooling are estimated for the population aged 25-55 in each case, which also avoids potential endogeneity.

Our base estimates are obtained through panel difference-in-difference regressions with Huber-corrected robust standard errors and country-year dummies, so our results control for time variant and invariant country characteristics and for non-observable cohort characteristics simultaneously. All regressions are performed for the total population and for males and females separately. All in all, we observe 226 episodes of change in the pooled data. We test with a series of specifications and report the models to verify the stability and consistency in the coefficient estimates.

\subsection{Base Results}

Table 3 presents the base regression for our analysis by introducing each group of variables parsimoniously. The first estimation shows a negative and statistically significant relationship between changes in school enrollment shares at USE ages for each cohort, and cohort size as measured by the fertility rate in the cohort's birth year. Similarly, as expected, there is a negative and significant relationship with changes in the (instrumented) share of LS enrolled individuals belonging to the poorest 40 percent in the income distribution, and changes in USE enrollment.

Table 3. Relation between changes in share of individuals enrolled in school at USE ages and context variables (Estimation in differences-in-differences; full LA sample)

\begin{tabular}{|c|c|c|c|c|c|c|c|c|c|c|}
\hline \multirow[t]{3}{*}{ Variable } & \multicolumn{2}{|l|}{ (1) } & \multicolumn{2}{|l|}{ (2) } & \multicolumn{2}{|l|}{ (3) } & \multicolumn{2}{|l|}{ (4) } & \multicolumn{2}{|l|}{ (5) } \\
\hline & \multicolumn{2}{|c|}{ Demographic } & \multicolumn{2}{|l|}{ Macro } & \multicolumn{2}{|l|}{ Labor } & \multicolumn{2}{|l|}{ Returns to } & \multicolumn{2}{|l|}{ Base } \\
\hline & Variables & & Environment & & Market & & Schooling & & Regression & \\
\hline Cohort fertility rate at & -0.033 & $* * *$ & -0.028 & $* * *$ & -0.015 & $*$ & & $* *$ & -0.015 & ** \\
\hline year of birth & $(0.005)$ & & $(0.006)$ & & $(0.008)$ & & -0.015 & & $(0.007)$ & \\
\hline IV $\%$ of youth in poorest & -0.09 & $* * *$ & $-0.100^{*}$ & $* * *$ & -0.089 & $* * *$ & & $* * *$ & -0.092 & $* * *$ \\
\hline $40 \%$ that attend LS & $(0.019)$ & & $(0.025)$ & & $(0.026)$ & & -0.092 & & $(0.030)$ & \\
\hline PPP adjusted per capita & & & 0.026 & & -0.062 & & & & -0.079 & \\
\hline GDP & & & $(0.055)$ & & $(0.066)$ & & -0.079 & & $(0.074)$ & \\
\hline Inflation rate & & & -0.001 & $* * *$ & -0.001 & $* * *$ & -0.001 & $* * *$ & -0.001 & $* * *$ \\
\hline & & & $(0.000)$ & & $(0.000)$ & & $(0.000)$ & & $(0.000)$ & \\
\hline Real average wage & & & & & 0.111 & $* *$ & & $* *$ & 0.113 & $* *$ \\
\hline (population 25-45) & & & & & $(0.048)$ & & 0.113 & & $(0.049)$ & \\
\hline Employment rate & & & & & 0.15 & $* * *$ & & $* *$ & 0.165 & $* *$ \\
\hline (population 25-45) & & & & & $(0.039)$ & & 0.165 & & $(0.071)$ & \\
\hline Returns to Higher & & & & & & & & $*$ & 0.008 & * \\
\hline Education (pop. 25-55) & & & & & & & 0.009 & & $(0.005)$ & \\
\hline Returns to USE & & & & & & & & $* *$ & 0.013 & $* *$ \\
\hline (population 25-55) & & & & & & & 0.012 & & $(0.006)$ & \\
\hline
\end{tabular}




\begin{tabular}{|c|c|c|c|c|c|c|c|c|c|c|}
\hline Constant & $\begin{array}{l}-0.050 \\
(0.018)\end{array}$ & $* * *$ & $\begin{array}{l}-0.067 \\
(0.022)\end{array}$ & $* * *$ & $\begin{array}{l}-0.113 \\
\quad(0.027)\end{array}$ & $* * *$ & $\begin{array}{l}-0.110 \\
(0.026)\end{array}$ & $* * *$ & $\begin{array}{l}-0.110 \\
(0.026)\end{array}$ & $* * *$ \\
\hline Observations & 216 & & 216 & & 216 & & 216 & & 216 & \\
\hline R-squared & 0.139 & & 0.125 & & 0.193 & & 0.197 & & 0.236 & \\
\hline
\end{tabular}

Robust standard errors in parentheses.

$* * * \mathrm{p}<0.01, * * \mathrm{p}<0.05, * \mathrm{p}<0.10$.

The second estimation incorporates the macroeconomic variables. According to our results, the relation between changes in enrollment and GDP per capita growth is positive, but not statistically significant. However, there is a strong negative and significant association with the inflation rate, which suggests that USE enrollment declines when instability in the economic environment increases, as would be expected.

The third estimation incorporates labor market variables characterized by the average wage and employment levels for the 25-45 year old population in each year. Interestingly, the coefficient for the wage and employment variables are positive and statistically significant, which suggests that the positive income effect on USE enrollment derived from these variables prevails over the potential negative substitution effects (Note 25).

Finally the fourth regression includes returns to USE and to HE relative to Primary as calculated for the 25-55 age range. The sign of both coefficients is positive, as expected - with increasing returns leading to higher USE enrollment - but while statistical significance is high for returns to USE, it is only marginally different from zero for HE. The R-squared in the last regression considering all variables is about 23 percent, which indicates that the variables in question account for about one fifth of the explanation for the changes in enrollment over time.

Table 4. Relation between changes in share of individuals enrolled in school at USE ages and context variables (Estimation with fixed, random effects, and cohort dummies; full LA sample)

\begin{tabular}{|c|c|c|c|c|c|c|}
\hline \multirow[b]{2}{*}{ Variable } & \multicolumn{2}{|l|}{ (6) } & \multirow{2}{*}{$\begin{array}{c}\text { (7) } \\
\text { Random Effects }\end{array}$} & \multicolumn{3}{|c|}{$(8)$} \\
\hline & Fixed Effects & & & & Cohort Dummies & \\
\hline & -0.032 & $* * *$ & -0.035 & $* * *$ & -0.034 & $* * *$ \\
\hline \multirow[t]{2}{*}{ Cohort fertility rate at year of birth } & $(0.010)$ & & $(0.010)$ & & $(0.009)$ & \\
\hline & -0.084 & $* * *$ & -0.052 & $* *$ & -0.05 & $* * *$ \\
\hline \multirow[t]{2}{*}{ IV $\%$ of youth in poorest $40 \%$ that attend LS } & $(0.039)$ & & $(0.024)$ & & $(0.026)$ & \\
\hline & -0.011 & & 0.0187 & & 0.017 & \\
\hline PPP adjusted per capita GDP & $(0.034)$ & & $(0.057)$ & & $(0.049)$ & \\
\hline \multirow[t]{3}{*}{ Inflation rate } & -0.00001 & $* *$ & -0.00001 & $* * *$ & -0.00001 & $* * *$ \\
\hline & $(0.000)$ & & $(0.000)$ & & $(0.000)$ & \\
\hline & 0.101 & $* * *$ & 0.09 & $* *$ & 0.011 & * \\
\hline \multirow[t]{2}{*}{ Real average wage (population 25-45) } & $(0.026)$ & & $(0.043)$ & & $(0.059)$ & \\
\hline & 0.216 & $* *$ & 0.189 & $* * *$ & 0.195 & $* * *$ \\
\hline \multirow[t]{2}{*}{ Employment rate (population 25-45) } & $(0.114)$ & & $(0.059)$ & & $(0.074)$ & \\
\hline & 0.011 & * & 0.014 & & 0.015 & $* * *$ \\
\hline Returns to Higher Education (pop. 25-55) & $(0.006)$ & & $(0.009)$ & & $(0.007)$ & \\
\hline Returns to USE (population 25-55) & 0.015 & $* * *$ & 0.012 & $* * *$ & 0.013 & $* * *$ \\
\hline
\end{tabular}




\begin{tabular}{lccc}
\hline & $(0.005)$ & $(0.006$ & $(0.005)$ \\
Constant & $-0.165 * * *$ & $-0.035 * * *$ & $-0.035 * * *$ \\
& $(0.340)$ & $(0.034)$ & $(0.034)$ \\
Observations & & & 216 \\
R-squared & 216 & 206 & 236 \\
\hline
\end{tabular}

Robust standard errors in parentheses.

To test for the robustness of using differences in differences as a method of estimation, we conduct three alternative estimates. The first, regression (6) in Table 4 is a fixed effects OLS regression that instruments the share of individuals in the poorest 40 percent attending LS as before, and imposes less structure than in the previous estimations. The results lead to similar conclusions with the sign and statistical significance of all coefficients being similar to those in regression (5) - the only apparent difference being a negative, although non-significant, relationship between school enrollment and GDP per capita. The second is a random effects estimation that also leads to the same general conclusions - the only difference with respect to the base specification is that the coefficient for the returns to HE is not statistically significant. Finally, regression (8) replicates regression (5), but following Moffitt (1993) and Verbeek (2007) it also includes cohort dummies to account for possible composition differences across cohorts that arise because our data is from household surveys that include samples of individuals - which implies a cohort-age cell error that deviates from the true cohort-age means, and which could vary, among other things, due to changes in sample size across surveys. The central result is the high stability of the coefficient estimates. The only exception is the relation between USE dropout and HE returns, which in this case are also positive and highly statistically significant.

\subsection{Estimations for Different Samples}

We explore differences across genders by using regression (5) as a main point of reference (Table 5). We estimate the base regression for each gender by using the same independent variables as in Table 3, while the independent variable refers to only one gender at a time. In a separate regression, we use both gender-specific dependent variables and independent variables for wages, employment, and the returns to schooling.

Table 5. Relation between changes in school enrollment at USE ages and context variables (Differences in differences for males and females)

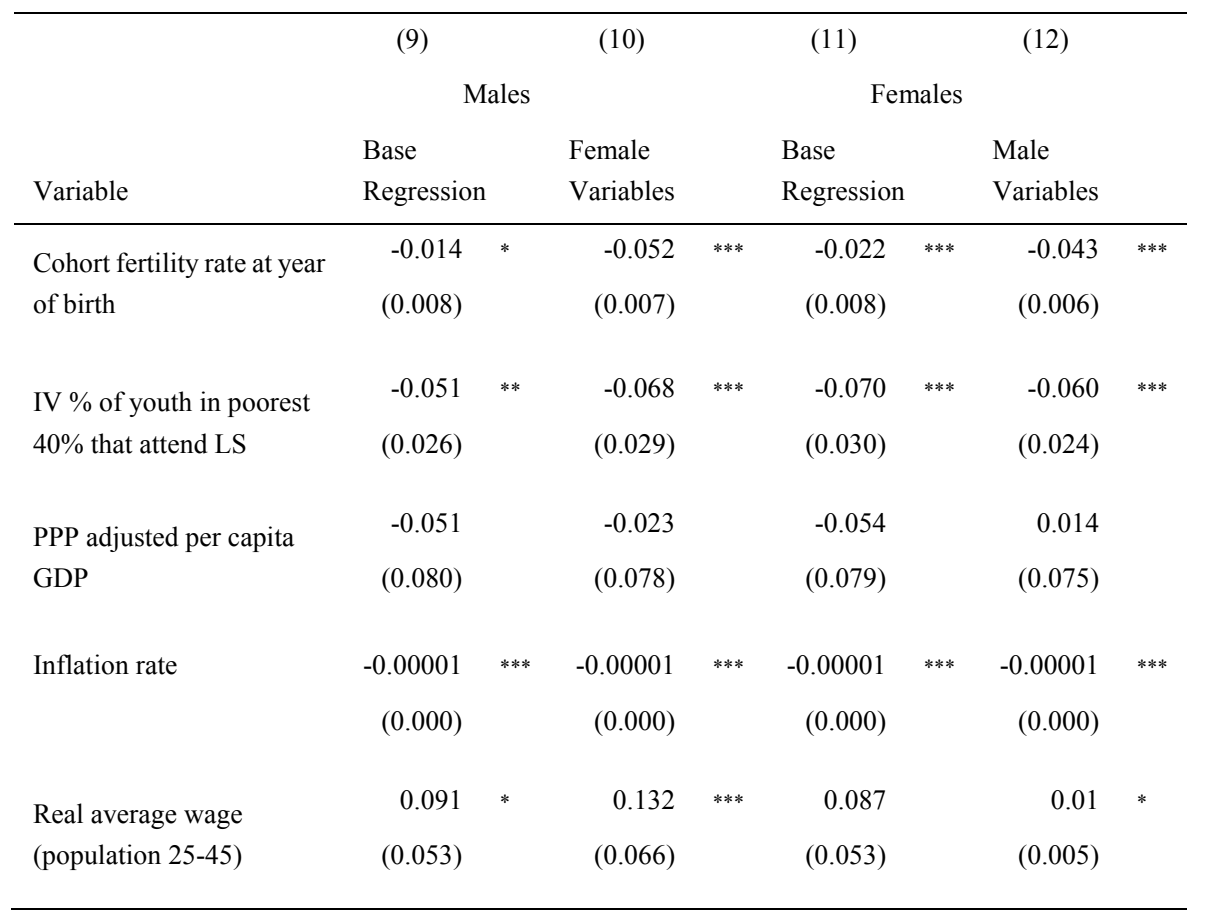




\begin{tabular}{|c|c|c|c|c|c|c|c|c|}
\hline $\begin{array}{l}\text { Employment rate } \\
\text { (population 25-45) }\end{array}$ & $\begin{array}{r}0.126 \\
(0.070)\end{array}$ & $* *$ & $\begin{array}{r}0.115 \\
(0.046)\end{array}$ & $* * *$ & $\begin{array}{r}0.16 \\
(0.078)\end{array}$ & $* *$ & $\begin{array}{r}0.135 \\
(0.065)\end{array}$ & ** \\
\hline $\begin{array}{l}\text { Returns to Higher } \\
\text { Education (pop. 25-55) }\end{array}$ & $\begin{array}{r}0.006 \\
(0.015)\end{array}$ & $*$ & $\begin{array}{r}0.019 \\
(0.009)\end{array}$ & $* * *$ & $\begin{array}{r}0.018 \\
(0.007)\end{array}$ & $* * *$ & $\begin{array}{r}0.009 \\
(0.008)\end{array}$ & \\
\hline $\begin{array}{l}\text { Returns to USE } \\
\text { (population 25-55) }\end{array}$ & $\begin{array}{r}0.022 \\
(0.006)\end{array}$ & $* * *$ & $\begin{array}{r}0.025 \\
(0.009)\end{array}$ & $* * *$ & $\begin{array}{r}0.027 \\
(0.007)\end{array}$ & $* * *$ & $\begin{array}{l}-0.019 \\
(0.009)\end{array}$ & ** \\
\hline Constant & $\begin{array}{l}-0.148 \\
(0.029)\end{array}$ & $* * *$ & $\begin{array}{l}-0.001 \\
(0.028)\end{array}$ & $* * *$ & $\begin{array}{l}-0.081 \\
(0.028)\end{array}$ & $* * *$ & $\begin{array}{l}-0.018 \\
(0.024)\end{array}$ & \\
\hline Observations & 216 & & 216 & & 216 & & 216 & \\
\hline R-squared & 0.147 & & 0.237 & & 0.187 & & 0.236 & \\
\hline
\end{tabular}

Robust standard errors in parentheses.

$* * * \mathrm{p}<0.01, * * \mathrm{p}<0.05, * \mathrm{p}<0.10$.

The most notable result is that most of the conclusions obtained from regression (5) remain for both genders, albeit with two main differences. The first is that the coefficient for wages is not significant for female USE age enrollment, while in the case of males this remains a statistically significant influence. Employment levels however, have a positive and statistically significant effect throughout, which suggests that it is labor opportunities rather than remuneration levels that lead females to stay longer in the schooling system.

The second difference has to do with the returns to HE. The coefficients in the case of females are highly significant when using the general returns as reference, but not for the gender specific HE rewards. In contrast, in both regressions the returns to USE are highly associated with female school enrollment. Another element of interest is that for males, most variables become of higher significance when using gender (male) specific indicators, which suggests that for males, specific gender related conditions are of more significance than changes in the labor market at large, as opposed to females.

Finally, we estimate our base regression separating countries into early, transition and late dropout as per the classification suggested in Section 3 (Table 6). We find an interesting difference across estimations in the relation with average wages and employment shares. Specifically, the coefficients for these variables are negative and statistically significant for countries with early dropout, which suggests for this category — which mostly includes low income countries with the exception of Colombia-substitution effects related to the opportunity cost of attending school can supersede the size of the income effects of the incentives provided by the labor market for remaining in school. This is consistent with generally having higher marginal propensities to consume at lower incomes, which lead to preferring current rather than future consumption. Other less significant differences are that the coefficients for changes in the returns to $\mathrm{HE}$ and for the share of poor individuals accessing LS are only marginally significant in the cases of late drop out and drop out in transition, respectively.

Table 6. Relation between changes in school enrollment at USE ages and context variables by groups of countries according to USE age dropout patterns

\begin{tabular}{|c|c|c|c|c|c|c|}
\hline \multirow{3}{*}{$\begin{array}{l}\text { Variable } \\
\text { Cohort fertility rate at } \\
\text { year of birth }\end{array}$} & \multicolumn{2}{|l|}{ (13) } & \multirow{2}{*}{\multicolumn{2}{|c|}{$\begin{array}{l}\quad(14) \\
\text { Transition } \\
\text { Dropout }\end{array}$}} & \multicolumn{2}{|l|}{ (15) } \\
\hline & Early Drop & & & & Late Drop & \\
\hline & $\begin{array}{l}-0.042 \\
(0.008)\end{array}$ & $* * *$ & $\begin{array}{l}-0.081 \\
(0.015)\end{array}$ & $* * *$ & $\begin{array}{l}-0.034 \\
(0.014)\end{array}$ & ** \\
\hline $\begin{array}{l}\text { IV } \% \text { of youth in poorest } \\
40 \% \text { that attend LS }\end{array}$ & $\begin{array}{l}-0.177 \\
(0.074)\end{array}$ & $* *$ & $\begin{array}{l}-0.102 \\
(0.071)\end{array}$ & $*$ & $\begin{array}{l}-0.131 \\
(0.069)\end{array}$ & ** \\
\hline
\end{tabular}




\begin{tabular}{|c|c|c|c|c|c|c|}
\hline PPP adjusted per capita & 0.132 & & 0.493 & & -0.252 & $* * *$ \\
\hline GDP & $(0.126)$ & & $(0.313)$ & & $(0.071)$ & \\
\hline Inflation rate & $\begin{array}{l}-0.0001 \\
(0.000)\end{array}$ & $* * *$ & $\begin{array}{l}-0.001 \\
(0.003)\end{array}$ & & $\begin{array}{l}-0.0001 \\
(0.000)\end{array}$ & $* * *$ \\
\hline $\begin{array}{l}\text { Real average wage } \\
\text { (population 25-45) }\end{array}$ & $\begin{array}{l}-0.041 \\
(0.022)\end{array}$ & $*$ & $\begin{array}{r}0.122 \\
(0.030)\end{array}$ & $* * *$ & $\begin{array}{r}0.147 \\
(0.038)\end{array}$ & $* * *$ \\
\hline $\begin{array}{l}\text { Employment rate } \\
\text { (population 25-45) }\end{array}$ & $\begin{array}{l}-0.077 \\
(0.044)\end{array}$ & $*$ & $\begin{array}{r}0.051 \\
(0.005)\end{array}$ & $* * *$ & $\begin{array}{r}0.059 \\
(0.026)\end{array}$ & $* * *$ \\
\hline $\begin{array}{l}\text { Returns to Higher } \\
\text { Education (pop. 25-55) }\end{array}$ & $\begin{array}{r}0.022 \\
(0.010)\end{array}$ & $* *$ & $\begin{array}{r}0.087 \\
(0.019)\end{array}$ & $* * *$ & $\begin{array}{r}0.058 \\
(0.032)\end{array}$ & $*$ \\
\hline $\begin{array}{l}\text { Returns to USE } \\
\text { (population 25-55) }\end{array}$ & $\begin{array}{r}0.032 \\
(0.013)\end{array}$ & $* *$ & $\begin{array}{r}0.073 \\
(0.022)\end{array}$ & $* * *$ & $\begin{array}{r}0.068 \\
(0.039)\end{array}$ & $* * *$ \\
\hline Constant & $\begin{array}{l}-0.034 \\
(0.037)\end{array}$ & $* * *$ & $\begin{array}{l}-0.518 \\
(0.058)\end{array}$ & $* * *$ & $\begin{array}{l}-0.028 \\
(0.046)\end{array}$ & \\
\hline Observations & 68 & & 45 & & 103 & \\
\hline R-squared & 0.2185 & & 0.299 & & 0.208 & \\
\hline
\end{tabular}

Robust standard errors in parentheses.

$* * * \mathrm{p}<0.01,{ }^{* *} \mathrm{p}<0.05, * \mathrm{p}<0.10$.

\section{Conclusions}

This study implements a synthetic cohort approach to trace schooling trajectories over the life cycle of different generations over time. We find that, in spite of increasing overall school enrollment rates across the region and a more favorable macroeconomic and labor market environment during the $21^{\text {st }}$ century, dropout rates at USE ages have not only remained at high levels after about 20 years, but have even increased markedly in several countries.

We explore the possible causes of USE age dropout in the region, by focusing on three groups of factors. First, we find that increasing shares of lower income youth completing LS are significantly associated with higher USE age dropout across the region. The interpretation of this result is that with the expansion of education, more vulnerable individuals increased the student population at a time when schools were not equipped to address their particular needs. This implies a need for education expansion to be accompanied by policies such as teacher training and early childhood development to enhance schools' capabilities for receiving and retaining such youth from early ages, as part of an overall strategy to reduce USE age dropout. Another direct implication is the need for mechanisms for addressing diversity in second chance programs.

Secondly, we find that the sharp decline in inflation rates is strongly linked to higher retention. Overall this has not resulted in declines in USE dropout due to other factors interacting simultaneously. In fact, it could be argued that had the economic environment not been as stable, USE age dropout might have been larger during the 2000s. This result has implications for devising dropout reduction strategies in LA reaching beyond education policy. Specifically, it points to the utility of smoothing mechanisms - such as scholarships, short term loans, or access to the financial system for vulnerable student populations. In relevant countries, guaranteeing that education systems can respond to shocks where needed, perhaps through linkage with existing social protection mechanisms, can be an important element of support for avoiding dropout. 
Thirdly, we find that positive "pull factors" associated with an income effect prevailing across the region, and mostly so for males - for females the effect of increasing employment opportunities seems to be greater than the wage level effect. We further find that in countries with early dropout, the substitution effect of "pulling" youth away from school when wages and employment opportunities are significant. Since the early dropout group is composed mainly of low income countries, it appears that substitution effects become more important at lower income levels.

These results suggest that supporting family capacities for financing schooling investments at USE ages is critical. The fact that the income effect prevails over possible substitution effects when incomes increase indicates that in general, families tend to privilege investment in human capital when they are able to do so. Interventions such as income transfers based on school attendance would be a logical policy response. A critical issue would be fine tuning scholarship programs to guarantee that income support addresses both building families' investment capacities and compensating for the opportunity cost of remaining in school (Note 26).

Additionally, we analyze the link with education returns. As expected, we find the returns to USE positively and strongly associated to school enrollment at the relevant USE ages, although in the case of HE the picture is more mixed. One interpretation is that USE age individuals may perceive that enrollment into HE is uncertain, so the market's value of USE graduation generally influences their decisions more strongly. HE returns, however, are only a significant element in some cases. The policy implication derived from this last result is that relevance is critical for increasing school enrollment at USE ages. If USE graduation is signaled as of high economic value our estimates suggest that LA youth respond by continuing in the schooling system longer.

\section{Acknowledgments}

The authors would like to thank Emanuela Di Gropello and Maria Marta Ferreyra for thoughtful comments and suggestions. The inputs and support received from Melissa Merchant, Elizabeth Monroy and Pamela Mendoza are also gratefully acknowledged.

\section{References}

Aedo, C., \& Ian, W. (2012). Skills for the 21st Century in Latin America and the Caribbean. World Bank, Washington, DC. https://doi.org/10.1596/978-0-8213-8971-3

Alfonso, M., Bos, M. S., Duarte, J., \& Rondón, C. (2012). Panorama general de la educación en América Latina y el Caribe. In M. Cabrol, \& M. Székely (Eds.), Educación para la transformación (Chapter 1). Banco Inter Americano de Desarrollo.

Attanasio, O. (1993). A cohort analysis of saving behavior by U.S. households. NBER Working Paper Series No. 4454.

Attanasio, O. (1998). Cohort analysis of saving behavior by U.S. households. Journal of Human Resources, 33(3), 575-609. https://doi.org/10.2307/146334

Attanasio, O., \& Banks, J. (1998). Trends in household saving don't justify tax incentives to boost saving. Economic Policy, 13(27), 549-583. https://doi.org/10.1111/1468-0327.00040

Attanasio, O., \& Székely, M. (2001). Household saving in East Asia and Latin America: Inequality, demographics, and all that. In Annual World Bank Conference on Development Economics 2000 (pp. 393-438).

Bassi, M., Busso, M., Urzúa, S., \& Muñoz, J. S. (2013). Is the glass half empty or half full?: School enrollment, graduation and dropout rates in Latin America. Inter-American Development Bank.

Becker, G. S. (1975). Human Capital (2nd ed.). New York, NY: NBER.

Becker, G. S. (1991). A Treatise on the Family (2nd ed.). Cambridge, MA: Harvard University Press.

Behrman, J. R., Duryea, S., \& Székely, M. (2006). Schooling investments and macroeconomic conditions: A household survey-based approach for Latin America and the Caribbean. In E. Fernandez-Arias, R. Manuelli, \& J. Blyde (Eds.), Sources of Growth in Latin America: What is Missing? Banco InterAmericano de Desarrollo, Washington DC.

Behrman, J. R., Pollak, R. A., \& Taubman, P. (1982). Parental preferences and provision for progeny. Journal of Political Economy, 90(1), 52-73. https://doi.org/10.1086/261039

Behrman, J. R., Pollak, R. A., \& Taubman, P. (1995). From Parent to Child: Intrahousehold Allocations and Intergenerational Relations in the United States. Chicago, IL: University of Chicago Press. 
Behrman, J. R., Rosenzweig, M. R., \& Taubman, P. (1994). Endowments and the allocation of schooling in the family and in the marriage market: The twins experiment. Journal of Political Economy, 102(6), 1131-1174. https://doi.org/10.1086/261966

Behrman, J. R., Rosenzweig, M. R., \& Taubman, P. (1996). College choice and wages: Estimates using data on female twins. Review of Economics and Statistics, 73(4), 672-685. https://doi.org/10.2307/2109954

Bentaouet Kattan, R., \& Székely, M. (2014). Dropout in upper secondary education in mexico: Patterns, consequences and possible causes. The World Bank, Washington, D.C. https://doi.org/10.1596/1813-9450-7083

Berlinski, S., Galiani, S., \& Manacorda, M. (2008). Giving children a better start: Preschool attendance and school-age profiles. Journal of Public Economics, 92(5-6), 1416-1440. https://doi.org/10.1016/j.jpubeco.2007.10.007

Bourguignon, F. (1998). Distributional Incidence of Education Expenditures: Intergenerational and Capital Market Effects. The World Bank, and Delta, Paris, mimeo.

Browning, M., Deaton, A., \& Irish, M. (1985). A profitable approach to labour supply and commodity demands over the life cycle. Econometrica, 53(3), 503-544. https://doi.org/10.2307/1911653

Cabrol, M. (2002). Los desafios de la educación secundaria: Qué nos dicen los análisis de flujos? Banco Interamericano de Desarrollo, Washington, DC.

Cameron, S. V., \& Heckman, J. (1998). Lifecycle schooling and the dynamic selection bias: Models and evidence for five cohorts of american males. Journal of Political Economy, 106(2), 262-333. https://doi.org/10.1086/250010

Cameron, S. V., \& Heckman, J. (2001). The dynamics of educational attainment for Black, Hispanic, and White males. Journal of Political Economy, 109(3), 455-499. https://doi.org/10.1086/321014

Case, A., \& Paxson, C. (2008). Stature and status: Height, ability, and labor market outcomes. Journal of Political Economy, 3(116), 499-532. https://doi.org/10.1086/589524

Chiu, H. (1998). Income inequality, schooling accumulation and economic performance. The Economic Journal, 108(January), 44-59. https://doi.org/10.1111/1468-0297.00272

Cuadra, E., \& Moreno, J. M. (2005). Expanding Opportunities and Building Competencies for Young People: A New Agenda for Secondary Education. Directions in Development, The World Bank, Washington DC.

Cunha, F., \& Heckman, J. (2007). The technology of skill formation. American Economic Review, 97(2), 31-47. https://doi.org/10.1257/aer.97.2.31

Cunha, F., \& Heckman, J. (2008). Symposium on noncognitive skills and their development: Formulating, identifying and estimating the technology of cognitive and noncognitive skill formation. Journal of Human Resources, 43(4), 738-782. https://doi.org/10.1353/jhr.2008.0019

Cunha, F., Heckman, J., Lochner, L., \& Masterov, D. (2006). Interpreting the evidence on life cycle skill formation. In Handbook of the Economics of Education (Vol. 1). https://doi.org/10.1016/S1574-0692(06)01012-9

Cunningham, W., McGinnis, L., Verdú, R. G., Tesliuc, C., \& Verner, D. (2008). Youth at Risk in Latin America and the Caribbean: Understanding the Causes, Realizing the Potential. Washington, D.C.: The World Bank. https://doi.org/10.1596/978-0-8213-7520-4

Dang, H., Lanjouw, P., Luoto, J., \& McKenzie, D. (2012). Using Repeated Cross-Sections to Explore Movements into and out of Poverty. Washington, D.C.: The World Bank.

De Ferranti, D., Perry, G. E., Gill, I., Guasch, J. L., Maloney, W. E., Sánchez-Páramo, C., \& Schady, N. (2003). Closing the Gap in Education and Technology. Washington D.C.: The World Bank. https://doi.org/10.1596/0-8213-5172-9

Deaton, A. (1985). Panel data from time series of cross-sections. Journal of Econometrics, 30, 109-126. https://doi.org/10.1016/0304-4076(85)90134-4

Deaton, A., \& Paxson, C. (1998). Saving and growth: Another look at the cohort evidence. 
Di Gropello, E. (2006). Meeting the Challenges of Secondary Education in Latin American and East Asia: Improving efficiency and resource mobilization. Washington, D.C.: The World Bank. https://doi.org/10.1596/978-0-8213-6645-5

Duryea, S., \& Arends-Kuenning, M. P. (2003). School attendance, child labor and local labor market fluctuations in urban Brazil. World Development, 31(7), 1165-1178. https://doi.org/10.1016/S0305-750X(03)00065-2

Duryea, S., Lam, D., \& Levinson, D. (2007). Effects of economic shocks on children's employment and schooling in Brazil. Journal of Development Economics, 84(1), 188-214. https://doi.org/10.1016/j.jdeveco.2006.11.004

Edmonds, E., Pavcnick, N., \& Topalova, P. (2010). Trade adjustments and human capital investments: Evidence from Indian tariff reform. American Economic Journal: Applied Economics, 2(4), 42-75. https://doi.org/10.1257/app.2.4.42

Engerman, S., Haber, S., \& Sokoloff, K. (1998). Inequality, Institutions and Differential Paths of Growth among the New World Economies. Mimeo, University of California at Los Angeles.

Fiszbein, A., \& Schady, N. (2009). Conditional Cash Transfers: Reducing Present and Future Poverty. World Bank Publications. https://doi.org/10.1596/978-0-8213-7352-1

Flug, K., Spilimbergo, S., \& Wachtenheim, E. (1998). Investment in education: Do economic volatility and credit constraints matter? Journal of Development Economics, 55(2), 465-481. https://doi.org/10.1016/S0304-3878(98)00045-5

Foster, A., \& Rosenzweig, M. (2004). Technological change and the distribution of schooling: Evidence from green-revolution India. Journal of Development Economics, 74(1), 87-111. https://doi.org/10.1016/j.jdeveco.2003.12.005

Friedman, J., \& Levinsohn, J. (2002). The distributional impacts of Indonesia's financial crisis on household welfare: A "rapid response" methodology. The World Bank Economic Review, 16(3), 397-423. https://doi.org/10.1093/wber/lhf001

Funkhouser, E. (1999). Cyclical economic conditions and school attendance in Costa Rica. Economics of Education Review, 18(1), 31-50. https://doi.org/10.1016/S0272-7757(97)00053-8

Grantham-McGregor, S., \& Cornelius, A. (2001). A review of studies on the effect of iron deficiency on cognitive development in children. Journal of Nutrition, 131, 649S-668S.

Heckman, J., \& Lafontaine, P. (2010). The American high school graduation rate: Trends and levels. Review of Economic and Statistics, 92(2), 244-262. https://doi.org/10.1162/rest.2010.12366

Heckman, J., Stixrud, J., \& Urzúa, S. (2006). The effects of cognitive and non cognitive abilities on labor market outcomes and social behavior. Journal of Labor Economics, 24, 411-482. https://doi.org/10.1086/504455

Heller, S., Pollack, H., Ander, R., \& Ludwig, J. (2013). Preventing Youth Violence and Dropout: A Randomized Experiment. NBER Working Paper 19014. https://doi.org/10.3386/w19014

Jacoby, H., \& Skoufias, E. (1997). Risk, financial markets and schooling in a developing country. Review of Economic Studies, 64(3), 311-335. https://doi.org/10.2307/2971716

Keane, J. (2009). What the economic crisis means for child labor. Global Social Policy, 9(supp.), 175-196. https://doi.org/10.1177/1468018109106890

Kundsen, E. (2006). Sensitive periods in the development of the brain and behavior. Journal of Cognitive Neuroscience, 16(8), 1412-1425.

Levy, S., \& Schady, N. (2013). Latin America's social policy challenge: Education, social insurance, redistribution. Journal of Economic Perspectives, 27(2), 193-218. https://doi.org/10.1257/jep.27.2.193

López-Calva, L. F., \& Lustig, N. (2010). Declining Inequality in Latin America: A Decade of Progress? United Nations Development Programme, New York, N.Y., Brookings Institution Press, Washington, D.C.

Maluccio, J. A., Hoddinott, J., Behrman, J. R., Quisumbing, A., Martorell, R., \& Stein, A. D. (2008). The Impact of Nutrition During Early Childhood on Education among Guatemalan Adults. Philadelphia-Washington-Atlanta: University of Pennsylvania, IFPRI, Emory, processed. 
McIntyre, F., \& Pencavel, J. (2004). The effect of macroeconomic turbulence on real wage levels and the wage structure: Brazil, 1981-1999. Economic Development and Cultural Change, 52, 681-717. https://doi.org/10.1086/381118

McKenzie, D. J. (2003). How do households cope with aggregate shocks? Evidence from the Mexican Peso crisis. World Development, 31(7), 1179-1199. https://doi.org/10.1016/S0305-750X(03)00064-0

Mehrotra, S. (2009). The impact of the economic crisis on the informal sector and poverty in East Asia. Global Social Policy, 9(1), 101-118. https://doi.org/10.1177/1468018109106887

Mendoza, R. (2009). Aggregate shocks, poor households and children: Transmission channels and policy responses. Global Social Policy, 9(supp.), 55-78. https://doi.org/10.1177/1468018109106885

Moffitt, R. (1993). Identification and estimation of dynamic models with a time series of repeated cross sections. Journal of Econometrics, 59, 99-123. https://doi.org/10.1016/0304-4076(93)90041-3

Mulligan, C. B. (1997). Parental Priorities and Economic Inequality. Chicago: University of Chicago Press.

OECD. (2011). Upper Secondary Completion: An OECD Overview. Paris: Organization for Economic Co-Operation and Development.

Organización de Estados Iberoamericanos (OEI). (2010). 2021: Metas Educativas. Madrid.

Paxson, C., \& Schady, N. (2007). Cognitive development among young children in Ecuador the roles of wealth, health, and parenting. Journal of Human Resources, 42(1), 49-84. https://doi.org/10.3368/jhr.XLII.1.49

Ramesh, M. (2009). Economic crisis and its social impacts: Lessons from the 1997 Asian economic crisis. Global Social Policy, 9, 79-99. https://doi.org/10.1177/1468018109106886

Reimers, F. (1991). The impact of economic stabilization and adjustment on education in Latin America. Comparative Education Review, 35(2), 319-353. https://doi.org/10.1086/447020

Rodriguez Planas, N. (2010). Longer-term impacts of mentoring, educational services, and incentives to learn: Evidence from a randomized trial. IZA Discussion Paper No. 4754.

Rosenzweig, M. R. (1990). Population growth and human capital investments: Theory and evidence. Journal of Political Economy, 98(5, part 2), S38-S71. https://doi.org/10.1086/261724

Schady, N. (2004). Do macroeconomic crises always slow human capital accumulation? World Bank Economic Review, 18(2), 131-154. https://doi.org/10.1093/wber/lhh036

Schady, N. (2012). El desarrollo infantil temprano en América Latina y el Caribe: Acceso, resultados y evidencia longitudinal de Ecuador. In M. Cabrol, \& M. Székely (Eds.), Educación para la Transformación. Inter-American Development Bank.

Shang, X., \& Wu, X. (2003). Protecting children under financial constraints: "Foster Mother Villages" in Datong. Journal of Social Policy, 32(4), 549-570. https://doi.org/10.1017/S0047279403007141

Shorrocks, A. F. (1975). The age-wealth relationship: A cross-section and cohort analysis. The Review of Economics and Statistics, 57, 155-163. https://doi.org/10.2307/1923996

Spilimbergo, A., Londoño, J. L., \& Székely, M. (1999). Income distribution, factor endowments and trade openness. Journal of Development Economics, 59, 77-101. https://doi.org/10.1016/S0304-3878(99)00006-1

Spinks, S. (2003). Adolescent Brains are Work in Progress. PBS Frontline.

Székely, M. (2014). Evaluación del programa de formación de recursos humanos basada en competencias. Centro de Estudios Educativos y Sociales and Inter American Development Bank, Washington, DC.

Székely, M., \& Karver, J. (2014). Youth out of school and out of work in Latin America: A cohort analysis. Mimeo, World Bank project on Out of School and Out of Work Youth in Latin America.

United Nations Educational, Scientific and Cultural Organization UNESCO. (2005). Secondary Education Reform: Towards a Convergence of Knowledge Acquisition and Skills Development. UNESCO, Paris.

Vegas, E., \& Santibáñez, L. (2010). La Promesa del Desarrollo en la Primera Infancia en América Latina y El Caribe. Banco Mundial.

Verbeek, M. (2007, November). Pseudo panels and repeated cross-sections. NBER Working Paper Series. 
Wolff, L., \& de Moura Castro, C. (2000). Secondary Education in Latin America and the Caribbean: The Challenge of Growth and Reform. Technical Paper Series EDU-111, Sustainable Development Department, The World Bank, Washington DC.

World Bank. (2005). Improving Educational Quality through Interactive Radio Instruction: A Toolkit for Policy Makers and Planners. Africa Region Human Development, Working Papers Series No. 52.

World Bank. (2012). Improving Access to Jobs and Earning Opportunities: The Role of Activation and Graduation Policies in Developing Countries. The World Bank.

\section{Notes}

Note 1. The official 2021 USE attendance rate targets set by countries in the region (OEI (2010)) reflect this priority, as well as UNESCO's education reform roadmap (2005). Outside the region, concern for this topic is shown, for example by Heckman and Lafontaine (2010) and Murane (2013) for the United States.

Note 2. Risks related to adolescence include teenage pregnancy, addictions, exposure to violence, and crime, among others. Relevant publications include Cunningham et al. (2008), Rodriguez (2010), World Bank (2005, 2012), Duryea and Arends-Kuenning (2003), Heller et al. (2013), and Bentaouet Kattan and Székely (2014).

Note 3. Duryea et al. (2003) and Spinks (2003), among others, illustrate this.

Note 4. There is considerable international literature on the subject. Murane (2013), for example, analyzes the stagnation in USE graduation rates in the United States and summarizes a large number of relevant studies. The author identifies factors affecting USE school attendance ranging from the supply and quality of services, to access to economic resources, to the family environment at birth and early childhood, to risk exposure, etc.

Note 5. Related studies with a LA regional perspective include Wolff and de Moura (2000), Cabrol (2002), De Ferranti et al. (2003), Cuadra and Moreno (2005), Reimers (1991), Behrman et al. (2006), Di Gropello (2006), Duryea, Lam, and Levinson (2007), Aedo and Walker (2012), Alfonso et al. (2012), Bassi et al. (2013), and Székely (2014). These studies analyze regional trends, but do not attempt to explain the dropout phenomenon explicitly. Country study examples include Blinder (1999), McKenzie (2003), Bentaouet Kattan and Székely (2014) for Mexico; Schady (2004), Funkhouser (1999), and McIntyre and Pencavel (2004) for Peru, Costa Rica, and Brazil, respectively; Duryea and Arends-Kuenning (2003) in Brazil; Berlinski et al. (2008) in Uruguay; and Maluccio et al. (2008) in Guatemala.

Note 6. See SEDLAC (2010), Levy and Schady (2013), and López Calva and Lustig (2010) for trends. Growth statistics are from the World Development Indicators (WDI), 2014.

Note 7. See Alfonso et al. (2012), Bassi et al. (2013), and Székely (2014).

Note 8. See Grantham-McGregor et al. (2001), Schady (2012), Case and Paxson (2008), Paxson and Schady (2007), Cunha and Heckman (2007), Cunha et al. (2006), Vegas and Santibañez (2010), Kundsen et al. (2006), and various works by Heckman, which measure the effects of early life events on education and other outcomes.

Note 9. Several countries collect panel data for labor market surveys, but typically follow individuals for a reduced time, which is a shorter term perspective than we require. Education administrative records are not suited for a dynamic approach since they only register information on individuals in the schooling system.

Note 10. This approach has been used by Browning, Deaton, and Irish (1985), Shorrocks (1975), Moffit (1993), Deaton (1998), and Attanasio and Banks (1998) mainly to analyze savings behavior. Recent applications to other areas include Dang et al. (2012), Cruces, Fields and Viollaz (2013), and Székely and Karver (2014).

Note 11. Two problems of this type of cohort analysis are differential mortality and migration. (i) If mortality and schooling are correlated, estimated changes in attendance rates could be upward biased for example see Deaton and Paxson (1998) and Attanasio and Hoynes (1998). However, since our life cycle window of interest is relatively short and focused at early ages, we expect these effects to be small in our analysis. (ii) Differential immigration or migration associated with schooling can also introduce biases. Large inflows of low educated individuals in young cohorts can affect composition by underestimating schooling levels, and vice versa. We lack historical data on migration flows to assess the magnitude of this bias, but do not expect significant effects on our results since our analysis focuses on relatively young ages that are less prone to migration, and within a relatively short period of the life cycle.

Note 12. ICSED definitions at http://www.uis.unesco.org/Education/ISCEDMappings/Pages/default.aspx 
Note 13. Since our data base generates an unbalanced panel of countries and years due to differences in timing of the surveys we compute averages by interpolating values for each country between each two points in time for which there is data. The averages are not population weighted, although a similar picture emerges when using population weights.

Note 14. Cohorts born earlier will start being observed when they are already 18 years of age or more, so information on their trajectories is beyond our analysis' scope.

Note 15. See Attanasio (1993), Attanasio and Banks (1998), Attanasio (1998), and Attanasio and Székely (2001).

Note 16. To implement the identification procedure we compute the cohort median age. Since we are interested in cell means (which represent the proportion enrolled in school) we first consider our indicator of interest as a function of cohort tendencies and an error term, which allow us to decompose the variability of a given indicator for each individual in a given year-cohort. Following Attanasio (1993) for each individual $i$ with a median age $a$ in cohort $c$ in time $t$, we consider the following: Xtaci $=\delta$ tc + staci, where $\delta$ represents cell means (in our case, the proportion of individuals enrolled in school), and $\varepsilon$ is a random error (deviations from $\delta$ ) with the assumption that $\mathrm{E}[\varepsilon]=0$. Cell means are adjusted by cell size-cohorts with more individuals are weighted appropriately - and $\delta$ is estimated as a simple weighted proportion of enrollment. Having postulated a typical age profile of schooling we can consider any deviations of these indicators in the aggregate as cohort effects, since they capture differences across cohorts that cannot be accounted for by differences in age-under the assumption of equivalent time effects across cohorts. These deviations could also be considered a combination of age and time effects. Under the assumption that the $\delta$ tc represent cohort means for enrollment they can be expressed as polynomials in age, year of birth (cohort) and survey year (with constant $\alpha 0$ ). By taking the first differences of the polynomial we arrive at an equation that can be estimated to determine the shape of the age profile. Following Attanasio (1993), rather than estimating the equation directly, we smooth the cell means (that are essentially individual line plots per cohort) by regressing these cell means on a fifth order polynomial in age, c-1 dummies for each cohort, and t-1 dummies for each survey year, the latter constrained to sum up to zero and to be orthogonal to a linear (time) trend. The smoothed profiles assume that year effects are identical across cohorts. This would imply that all trends in the means can be interpreted as being the result of age and cohorts effects.

Note 17. Developments derived from Becker's original model include Becker (1991), Behrman, Pollak and Taubman (1982, 1995), Mulligan (1997), and Bourguignon (1998), among others. Murane (2013) discusses other developments as well.

Note 18. For this study we consider the economic costs and benefits of education, although there are broader gains and costs involved in schooling decisions. For instance, religious beliefs and cultural patterns may influence schooling decisions and can do so with large differences by gender. Additionally, the responsiveness of sector governing institutions to household demands for schooling can have strong effects on enrollments and attainment (see Engerman, Haber and Sokoloff (1998)).

Note 19. Other channels are that children's genetic endowments may interact with investment decisions (see Behrman, Rosenzweig and Taubman $(1994,1996))$, and through their relation with cognitive and socio emotional skills acquired at young ages (see Cameron and Heckman $(1998,2001)$, and Cunha and Heckman (2007, 2008)).

Note 20. According to the most WDI 2014 data, LA has universal primary school attendance, with completion levels close to 90 percent, and LS attendance over 90 percent. Alfonso et al. (2012) use household survey data and estimate similar attendance rates. Improvements in the region have been documented recently by Bassi, Busso and Muñoz (2013). LS education has become compulsory throughout the region for youth aged 12-14 - with the exceptions of Honduras and Nicaragua, where Primary education is still the only compulsory level. In some cases, USE is also compulsory by law, including Argentina, Brazil, Chile, Mexico, Peru, Uruguay, and República Bolivariana de Venezuela (See OEI (2010)).

Note 21. See Behrman, Duryea and Székely (2006).

Note 22. For shocks' effects on schooling investment due to liquidity constraints and absence of insurance see Chiu (1998), Duryea, Lam and Levinson (2007), Flug et al. (1998), Jacoby and Skoufias (1997, 2009), Mendoza (2009), Ramesh (2009), Mehrotra (2009), Keane (2009), Friedman and Levinsohn (2002), and Shang and Wu (2003). 
Note 23. Duryea and Arends-Kuenning (2003) for instance, find that in Brazil substitution effects prevailed for 14-16 year olds when labor market conditions improved, resulting in higher school dropout. Edmonds et al. (2010), however find in India that income effects prevailed during the period of trade liberalization, due to the relation between increased household resources and higher school enrollment.

Note 24. As discussed by Murane (2013), schooling's value can change through channels including higher productivity, exogenous economic factors, and changing value of school credentials related to socioeconomic status.

Note 25. In this specification and those following we also tested the inclusion of the share of participants in the formal sector as an independent variable. The coefficient is not statistically significant in practically any of the estimations. We therefore do not include it explicitly in the remaining analysis. We conclude that the level of wage remunerations rather than the type of employment, is what influences school enrollment decisions.

Note 26. A large literature confirms the positive effect of conditional cash transfers on retention in the education system (although predominantly at the Primary and LS levels). Summaries are compiled by Fiszbein and Schady (2009), and Fiszbein, Schady and Ferreira (2009), among others. Much less evidence is available for USE.

\section{Appendix A}

Table A.1. Years for which household surveys are available

\begin{tabular}{|c|c|c|c|c|c|c|c|c|c|c|c|c|c|c|c|c|c|c|c|c|c|c|}
\hline \multicolumn{8}{|l|}{ Country } & \multicolumn{14}{|c|}{ Years for which household survey is available } & \multirow{2}{*}{$\frac{\text { Total }}{21}$} \\
\hline Venezuela & 1981 & 1982 & 1983 & 1985 & 1986 & 1988 & 1989 & 1990 & 1992 & 1993 & 1995 & 1996 & 1997 & 1998 & 1999 & 2000 & 2001 & 2003 & 2004 & 2006 & 2007 & \\
\hline Brasil & 1981 & 1983 & 1986 & 1988 & 1992 & 1993 & 1995 & 1996 & 1997 & 1998 & 1999 & 2001 & 2002 & 2003 & 2004 & 2008 & 2009 & & & & & 17 \\
\hline Argentina & 1980 & 1996 & 1998 & 2000 & 2001 & 2002 & 2003 & 2004 & 2005 & 2006 & 2007 & 2008 & 2009 & 2010 & 2011 & & & & & & & 15 \\
\hline Honduras & 1989 & 1992 & 1996 & 1997 & 1998 & 1999 & 2001 & 2002 & 2003 & 2005 & 2007 & 2008 & 2009 & 2010 & 2011 & & & & & & & 15 \\
\hline Panamá & 1991 & 1995 & 1996 & 1997 & 1998 & 1999 & 2001 & 2002 & 2003 & 2004 & 2006 & 2007 & 2008 & 2009 & 2010 & & & & & & & 15 \\
\hline Peru & 1985 & 1991 & 1994 & 1996 & 2000 & 2001 & 2002 & 2003 & 2004 & 2005 & 2006 & 2008 & 2009 & 2010 & 2011 & & & & & & & 15 \\
\hline Paraguay & 1993 & 1994 & 1995 & 1996 & 1997 & 1998 & 1999 & 2000 & 2002 & 2003 & 2004 & 2008 & 2009 & 2010 & 2011 & & & & & & & 15 \\
\hline Colombia & 1980 & 1986 & 1989 & 1996 & 1997 & 1998 & 1999 & 2000 & 2003 & 2006 & 2007 & 2008 & 2009 & 2010 & & & & & & & & 14 \\
\hline Costa Rica & 1987 & 1989 & 1991 & 1993 & 1995 & 1997 & 1998 & 2000 & 2001 & 2002 & 2003 & 2004 & 2009 & 2010 & & & & & & & & 14 \\
\hline El Salvador & 1989 & 1992 & 1995 & 1996 & 1997 & 1998 & 1999 & 2000 & 2001 & 2002 & 2003 & 2004 & 2007 & 2008 & & & & & & & & 14 \\
\hline Uruguay & 1989 & 1992 & 1995 & 1997 & 1998 & 2001 & 2002 & 2003 & 2004 & 2005 & 2006 & 2007 & 2010 & 2011 & & & & & & & & 14 \\
\hline México & 1984 & 1989 & 1992 & 1994 & 1996 & 1998 & 2000 & 2002 & 2004 & 2005 & 2006 & 2008 & 2010 & & & & & & & & & 13 \\
\hline Dom. Rep. & 1995 & 1996 & 1997 & 2000 & 2001 & 2002 & 2003 & 2004 & 2007 & 2009 & 2010 & 2011 & & & & & & & & & & 12 \\
\hline Chile & 1987 & 1990 & 1992 & 1994 & 1996 & 1998 & 2000 & 2003 & 2006 & 2009 & & & & & & & & & & & & 10 \\
\hline Ecuador & 1995 & 1998 & 2000 & 2001 & 2003 & 2004 & 2008 & 2009 & 2010 & 2011 & & & & & & & & & & & & 10 \\
\hline Bolivia & 1995 & 1996 & 1997 & 1999 & 2001 & 2002 & 2008 & & & & & & & & & & & & & & & 7 \\
\hline Guatemala & 1998 & 2000 & 2004 & 2006 & 2009 & 2010 & 2011 & & & & & & & & & & & & & & & 7 \\
\hline Nicaragua & 1993 & 1998 & 2001 & 2005 & 2009 & 2010 & & & & & & & & & & & & & & & & 6 \\
\hline
\end{tabular}

Source: Extended data bank of household surveys.

Table A.2. Official age for attending different schooling levels

\begin{tabular}{lcccc}
\hline \multicolumn{1}{c}{ Country } & Pre-school & Primary & Lower Secondary & Upper Secondary \\
\hline Argentina & $3-5$ & $6-11$ & $12-14$ & $15-17$ \\
Bolivia & $4-5$ & $6-11$ & $12-13$ & $14-17$ \\
Brazil & $4-6$ & $7-10$ & $11-14$ & $15-18$ \\
Chile & $3-5$ & $6-11$ & $12-13$ & $14-17$ \\
Colombia & $3-5$ & $6-10$ & $11-14$ & $15-16$ \\
Costa Rica & 5 & $6-11$ & $12-14$ & $15-17$ \\
D. Republic & $3-5$ & $6-11$ & $12-13$ & $14-17$ \\
Ecuador & $4-5$ & $6-11$ & $12-14$ & $15-17$ \\
\hline
\end{tabular}




\begin{tabular}{lcccc}
\hline Guatemala & $3-6$ & $7-12$ & $13-15$ & $16-18$ \\
Honduras & $3-5$ & $6-11$ & $12-14$ & $15-16 / 17$ \\
Mexico & $3-5 / 6$ & $6-11$ & $12-14$ & $15-16 / 17$ \\
Nicaragua & $4-6$ & $7-12$ & $13-15$ & $16-17 / 18$ \\
Panama & $4-5$ & $6-11$ & $12-14$ & $15-17$ \\
Peru & $3-5$ & $6-11$ & $12-14$ & $15-16$ \\
Paraguay & $4-5$ & $6-11$ & $12-14$ & $15-17$ \\
El Salvador & $4-6$ & $7-12$ & $13-15$ & $16-18$ \\
Uruguay & $3-5$ & $6-11$ & $12-14$ & $15-17$ \\
Venezuela & $3-5$ & $6-11$ & $12-14$ & $15-16 / 17$ \\
\hline
\end{tabular}

Source: ICSED 1997, UNESCO, and country level official data for Costa Rica, Ecuador, and El Salvador.

Table A.3. School enrollment rate for individuals belonging to Cohort 2 (entering USE age in 1999-2001)

\begin{tabular}{|c|c|c|c|c|c|c|c|c|}
\hline \multirow[b]{2}{*}{ Country } & \multicolumn{8}{|c|}{ Year at which cohort is observed in ages 11 to 18} \\
\hline & $\begin{array}{c}11 \text { years of } \\
\text { age in } \\
1995\end{array}$ & $\begin{array}{c}12 \text { years of } \\
\text { age in } \\
1996\end{array}$ & $\begin{array}{c}13 \text { years of } \\
\text { age in } \\
1997\end{array}$ & $\begin{array}{c}14 \text { years of } \\
\text { age in } \\
1998\end{array}$ & $\begin{array}{c}15 \text { years of } \\
\text { age in } \\
1999\end{array}$ & $\begin{array}{c}16 \text { years of } \\
\text { age in } \\
2000\end{array}$ & $\begin{array}{c}17 \text { years of } \\
\text { age in } \\
2001\end{array}$ & $\begin{array}{c}18 \text { years of } \\
\text { age in } \\
2002\end{array}$ \\
\hline Argentina & $97 \%$ & $94 \%$ & $86 \%$ & $84 \%$ & $80 \%$ & $74 \%$ & $67 \%$ & \\
\hline Bolivia & $92 \%$ & $87 \%$ & $81 \%$ & $80 \%$ & $77 \%$ & $74 \%$ & $63 \%$ & \\
\hline Brasil & $90 \%$ & $87 \%$ & $84 \%$ & $81 \%$ & $76 \%$ & $69 \%$ & $59 \%$ & $49 \%$ \\
\hline Chile & $98 \%$ & $96 \%$ & $94 \%$ & $89 \%$ & $84 \%$ & $74 \%$ & $63 \%$ & \\
\hline Colombia & $90 \%$ & $80 \%$ & $78 \%$ & $75 \%$ & $66 \%$ & $55 \%$ & $44 \%$ & \\
\hline Costa Rica & $92 \%$ & $85 \%$ & $73 \%$ & $62 \%$ & $57 \%$ & $53 \%$ & $47 \%$ & \\
\hline Dominican R. & $85 \%$ & $77 \%$ & $72 \%$ & $66 \%$ & $61 \%$ & $54 \%$ & $49 \%$ & \\
\hline Ecuador & $80 \%$ & $74 \%$ & $69 \%$ & $62 \%$ & $50 \%$ & $42 \%$ & $33 \%$ & \\
\hline Guatemala & $80 \%$ & $70 \%$ & $60 \%$ & $50 \%$ & $37 \%$ & $34 \%$ & $31 \%$ & $27 \%$ \\
\hline Honduras & $83 \%$ & $71 \%$ & $56 \%$ & $46 \%$ & $39 \%$ & $33 \%$ & $30 \%$ & \\
\hline México & $89 \%$ & $82 \%$ & $75 \%$ & $63 \%$ & $51 \%$ & $46 \%$ & $41 \%$ & \\
\hline Nicaragua & $76 \%$ & $69 \%$ & $62 \%$ & $55 \%$ & $49 \%$ & $43 \%$ & $37 \%$ & $31 \%$ \\
\hline Panamá & $97 \%$ & $98 \%$ & $96 \%$ & $93 \%$ & $91 \%$ & $88 \%$ & $84 \%$ & \\
\hline Perú & $95 \%$ & $82 \%$ & $81 \%$ & $66 \%$ & $56 \%$ & $55 \%$ & $46 \%$ & \\
\hline Paraguay & $96 \%$ & $92 \%$ & $88 \%$ & $79 \%$ & $71 \%$ & $57 \%$ & $45 \%$ & \\
\hline El Salvador & $96 \%$ & $96 \%$ & $93 \%$ & $87 \%$ & $80 \%$ & $72 \%$ & $65 \%$ & $54 \%$ \\
\hline Uruguay & $94 \%$ & $91 \%$ & $84 \%$ & $78 \%$ & $71 \%$ & $62 \%$ & $54 \%$ & \\
\hline Venezuela & $94 \%$ & $92 \%$ & $87 \%$ & $77 \%$ & $67 \%$ & $54 \%$ & $46 \%$ & \\
\hline Average & $90 \%$ & $85 \%$ & $79 \%$ & $72 \%$ & $65 \%$ & $58 \%$ & $50 \%$ & $40 \%$ \\
\hline
\end{tabular}

Source: Author's calculations from household survey data.

Entry age for Lower Secondary. Entry age for Upper Secondary.

Exit age for Upper Secondary.

Table A.4. School enrollment rate for individuals belonging to Cohort 4 (entering USE age in 2009-2011)

\begin{tabular}{|c|c|c|c|c|c|c|c|c|}
\hline \multirow[b]{2}{*}{ Country } & \multicolumn{8}{|c|}{ Year at which cohort is observed in ages 11 to 18} \\
\hline & $\begin{array}{c}11 \text { years of } \\
\text { age in } \\
2005\end{array}$ & $\begin{array}{c}12 \text { years of } \\
\text { age in } \\
2006\end{array}$ & $\begin{array}{c}13 \text { years of } \\
\text { age in } \\
2007\end{array}$ & $\begin{array}{c}14 \text { years of } \\
\text { age in } \\
2008\end{array}$ & $\begin{array}{c}15 \text { years of } \\
\text { age in } \\
2009\end{array}$ & $\begin{array}{c}16 \text { years of } \\
\text { age in } \\
2010\end{array}$ & $\begin{array}{c}17 \text { years of } \\
\text { age in } \\
2011\end{array}$ & $\begin{array}{c}18 \text { years of } \\
\text { age in } \\
2012\end{array}$ \\
\hline Argentina & $99 \%$ & $99 \%$ & $97 \%$ & $94 \%$ & $90 \%$ & $87 \%$ & $76 \%$ & \\
\hline
\end{tabular}




\begin{tabular}{|c|c|c|c|c|c|c|c|c|}
\hline Bolivia & $99 \%$ & $98 \%$ & $96 \%$ & $87 \%$ & $81 \%$ & $76 \%$ & $70 \%$ & \\
\hline Brasil & $98 \%$ & $98 \%$ & $96 \%$ & $94 \%$ & $92 \%$ & $81 \%$ & $70 \%$ & $60 \%$ \\
\hline Chile & $99 \%$ & $99 \%$ & $98 \%$ & $98 \%$ & $96 \%$ & $94 \%$ & $93 \%$ & \\
\hline Colombia & $96 \%$ & $91 \%$ & $92 \%$ & $89 \%$ & $86 \%$ & $78 \%$ & $64 \%$ & \\
\hline Costa Rica & $99 \%$ & $95 \%$ & $93 \%$ & $89 \%$ & $86 \%$ & $79 \%$ & $76 \%$ & \\
\hline Dominican R. & $95 \%$ & $91 \%$ & $87 \%$ & $86 \%$ & $89 \%$ & $85 \%$ & $76 \%$ & \\
\hline Ecuador & $93 \%$ & $89 \%$ & $84 \%$ & $80 \%$ & $76 \%$ & $71 \%$ & $48 \%$ & \\
\hline Guatemala & $88 \%$ & $87 \%$ & $80 \%$ & $72 \%$ & $65 \%$ & $57 \%$ & $47 \%$ & $39 \%$ \\
\hline Honduras & $92 \%$ & $87 \%$ & $77 \%$ & $68 \%$ & $61 \%$ & $53 \%$ & $46 \%$ & \\
\hline México & $97 \%$ & $96 \%$ & $90 \%$ & $85 \%$ & $75 \%$ & $66 \%$ & $57 \%$ & \\
\hline Nicaragua & $91 \%$ & $83 \%$ & $75 \%$ & $67 \%$ & $64 \%$ & $61 \%$ & $59 \%$ & $43 \%$ \\
\hline Panamá & $97 \%$ & $98 \%$ & $98 \%$ & $96 \%$ & $94 \%$ & $90 \%$ & $86 \%$ & \\
\hline Perú & $96 \%$ & $95 \%$ & $91 \%$ & $86 \%$ & $79 \%$ & $71 \%$ & $70 \%$ & \\
\hline Paraguay & $76 \%$ & $77 \%$ & $77 \%$ & $77 \%$ & $73 \%$ & $63 \%$ & $51 \%$ & \\
\hline El Salvador & $98 \%$ & $98 \%$ & $98 \%$ & $96 \%$ & $91 \%$ & $84 \%$ & $76 \%$ & $69 \%$ \\
\hline Uruguay & $98 \%$ & $98 \%$ & $94 \%$ & $89 \%$ & $84 \%$ & $76 \%$ & $65 \%$ & \\
\hline Venezuela & $98 \%$ & $97 \%$ & $95 \%$ & $92 \%$ & $86 \%$ & $78 \%$ & $73 \%$ & \\
\hline Average LA & $95 \%$ & $93 \%$ & $90 \%$ & $86 \%$ & $82 \%$ & $75 \%$ & $67 \%$ & \\
\hline
\end{tabular}

Source: Author's calculations from household survey data.

Entry age for Lower Secondary. Entry age for Upper Secondary.

Exit age for Upper Secondary.

Table A.5. Change in the number of individuals that become eligible for attending USE by decade in LA

\begin{tabular}{|c|c|c|c|c|c|c|}
\hline \multirow[t]{3}{*}{ Country } & \multicolumn{3}{|c|}{$\begin{array}{c}\text { Additional 10-14 year olds } \\
\text { attending Primary }\end{array}$} & \multicolumn{3}{|c|}{$\begin{array}{l}\text { Additional } 15-20 \text { year olds } \\
\text { completing LS }\end{array}$} \\
\hline & \multicolumn{2}{|c|}{ (Thousands) } & \multirow[b]{2}{*}{$\%$ change } & \multicolumn{2}{|c|}{ (Thousands) } & \multirow[b]{2}{*}{$\%$ change } \\
\hline & $1990-2000$ & $2000-2010$ & & $1990-2000$ & $2000-2010$ & \\
\hline Argentina & 56.8 & 31.9 & $-44 \%$ & 491,476 & 506,841 & $3 \%$ \\
\hline Bolivia & 229.6 & 213.4 & $-7 \%$ & 124,717 & 274,616 & $120 \%$ \\
\hline Brazil & $3,004.00$ & $3,335.80$ & $11 \%$ & $2,624,332$ & $4,077,337$ & $55 \%$ \\
\hline Chile & 438.3 & -123.8 & $-128 \%$ & 115,903 & 187,962 & $62 \%$ \\
\hline Colombia & 839.8 & 361 & $-57 \%$ & 513,760 & 683,548 & $33 \%$ \\
\hline Costa Rica & 100.9 & 18.3 & $-82 \%$ & 104,205 & 125,244 & $20 \%$ \\
\hline Dominican R. & 175.3 & 164.2 & $-6 \%$ & 81,503 & 250,604 & $207 \%$ \\
\hline Ecuador & 323.3 & 123.5 & $-62 \%$ & 135,364 & 405,016 & $199 \%$ \\
\hline El Salvador & 187.8 & 111.7 & $-41 \%$ & 36,318 & 140,825 & $288 \%$ \\
\hline Guatemala & 182.1 & 576.8 & $217 \%$ & 144,663 & 395,137 & $173 \%$ \\
\hline Honduras & 245.9 & 156.4 & $-36 \%$ & 82,789 & 209,960 & $154 \%$ \\
\hline Mexico & $1,673.80$ & 827.9 & $-51 \%$ & $1,027,214$ & $1,853,930$ & $80 \%$ \\
\hline Nicaragua & 110.6 & 104.2 & $-6 \%$ & 63,298 & 91,664 & $45 \%$ \\
\hline Panama & 23.2 & 36.9 & $59 \%$ & 35,458 & 38,969 & $10 \%$ \\
\hline Paraguay & 232.7 & 58.4 & $-75 \%$ & 125,185 & 160,500 & $28 \%$ \\
\hline Peru & 484.9 & 73.9 & $-85 \%$ & 330,838 & 485,568 & $47 \%$ \\
\hline Uruguay & -9.2 & -0.6 & $-93 \%$ & 10,799 & 22,718 & $110 \%$ \\
\hline
\end{tabular}




\begin{tabular}{lrrrrrr}
\hline Venezuela & 426.6 & 340.6 & $-20 \%$ & 295,794 & 690,144 & $133 \%$ \\
Total LA & 8,726 & 6,411 & $-27 \%$ & $6,343,618$ & $10,600,581$ & $67 \%$ \\
\hline
\end{tabular}

Source: Author's calculations.

Table A.6. Share of LS age individuals belonging to hhs in bottom $40 \%$ of distribution that complete LS

\begin{tabular}{|c|c|c|c|c|c|}
\hline \multirow[t]{2}{*}{ Country } & \multicolumn{3}{|c|}{ Share of LS Age Youth completing LS } & \multicolumn{2}{|l|}{ Difference } \\
\hline & $1990 \mathrm{~s}$ & $2000 \mathrm{~s}$ & $2010 \mathrm{~s}$ & $1990-2000$ & $2000-2010$ \\
\hline Argentina & $67 \%$ & $68 \%$ & $70 \%$ & $2 \%$ & $2 \%$ \\
\hline Bolivia & $27 \%$ & $40 \%$ & $53 \%$ & $14 \%$ & $13 \%$ \\
\hline Brasil & $27 \%$ & $50 \%$ & $58 \%$ & $23 \%$ & $8 \%$ \\
\hline Chile & $44 \%$ & $51 \%$ & $71 \%$ & $7 \%$ & $20 \%$ \\
\hline Colombia & $42 \%$ & $45 \%$ & $61 \%$ & $3 \%$ & $16 \%$ \\
\hline CostaRica & $31 \%$ & $34 \%$ & $49 \%$ & $3 \%$ & $15 \%$ \\
\hline Dominican R & $20 \%$ & $27 \%$ & $46 \%$ & $7 \%$ & $19 \%$ \\
\hline Ecuador & $34 \%$ & $43 \%$ & $75 \%$ & $8 \%$ & $32 \%$ \\
\hline El Salvador & $19 \%$ & $27 \%$ & $39 \%$ & $8 \%$ & $12 \%$ \\
\hline Guatemala & $10 \%$ & $14 \%$ & $23 \%$ & $3 \%$ & $10 \%$ \\
\hline Honduras & $10 \%$ & $22 \%$ & $29 \%$ & $12 \%$ & $7 \%$ \\
\hline Mexico & $36 \%$ & $54 \%$ & $71 \%$ & $19 \%$ & $17 \%$ \\
\hline Nicaragua & $12 \%$ & $20 \%$ & $28 \%$ & $8 \%$ & $8 \%$ \\
\hline Panama & $42 \%$ & $54 \%$ & $60 \%$ & $12 \%$ & $6 \%$ \\
\hline Paraguay & $36 \%$ & $36 \%$ & $50 \%$ & $0 \%$ & $13 \%$ \\
\hline Peru & $35 \%$ & $38 \%$ & $41 \%$ & $3 \%$ & $3 \%$ \\
\hline Uruguay & $29 \%$ & $46 \%$ & $51 \%$ & $17 \%$ & $5 \%$ \\
\hline Venezuela & $46 \%$ & $58 \%$ & $66 \%$ & $11 \%$ & $9 \%$ \\
\hline Average LA & $31 \%$ & $40 \%$ & $52 \%$ & $9 \%$ & $12 \%$ \\
\hline
\end{tabular}

Source: Author's calculations.

Table A.7. Annual GDP per capita growth and inflation rate in LA, 1990s-2000s

\begin{tabular}{|c|c|c|c|c|}
\hline \multirow[t]{2}{*}{ Country } & \multicolumn{2}{|c|}{ Annual GDP per capita Growth Rate } & \multicolumn{2}{|c|}{ Average Inflation Rate } \\
\hline & $1900-2000$ & $2000-2010$ & $1900-2000$ & $2000-2010$ \\
\hline Argentina & $2.9 \%$ & $3.60 \%$ & $27 \%$ & $14 \%$ \\
\hline Bolivia & $1.4 \%$ & $2.00 \%$ & $13 \%$ & $5 \%$ \\
\hline Brasil & $0.9 \%$ & $2.50 \%$ & $9 \%$ & $8 \%$ \\
\hline Chile & $5.4 \%$ & $2.90 \%$ & $13 \%$ & $3 \%$ \\
\hline Colombia & $0.8 \%$ & $2.60 \%$ & $47 \%$ & $7 \%$ \\
\hline Costa Rica & $2.7 \%$ & $2.60 \%$ & $31 \%$ & $15 \%$ \\
\hline Dominican Republic & $4.6 \%$ & $4.10 \%$ & $15 \%$ & $19 \%$ \\
\hline Ecuador & $-0.1 \%$ & $2.30 \%$ & $51 \%$ & $11 \%$ \\
\hline El Salvador & $3.7 \%$ & $1.40 \%$ & $10 \%$ & $4 \%$ \\
\hline Guatemala & $1.7 \%$ & $0.80 \%$ & $18 \%$ & $8 \%$ \\
\hline Honduras & $0.8 \%$ & $2.10 \%$ & $39 \%$ & $10 \%$ \\
\hline Mexico & $1.6 \%$ & $0.60 \%$ & $40 \%$ & $5 \%$ \\
\hline Nicaragua & $1.2 \%$ & $1.70 \%$ & $19 \%$ & $11 \%$ \\
\hline Panama & $3.0 \%$ & $4.90 \%$ & $1 \%$ & $3 \%$ \\
\hline
\end{tabular}




\begin{tabular}{lcccc}
\hline Paraguay & $0.0 \%$ & $1.50 \%$ & $23 \%$ & $10 \%$ \\
Peru & $2.2 \%$ & $4.90 \%$ & $14 \%$ & $2 \%$ \\
Uruguay & $2.4 \%$ & $3.30 \%$ & $45 \%$ & $12 \%$ \\
Venezuela & $0.0 \%$ & $1.30 \%$ & $18 \%$ & $59 \%$ \\
Latin America & $2.0 \%$ & $2.5 \%$ & $24.1 \%$ & $11.5 \%$ \\
\hline
\end{tabular}

Source: Calculations from ECLAC indicators system (http://estadisticas.cepal.org/cepalstat).

Table A.8 Indicators of the Labor Market environment in LA 1990s-2010s

\begin{tabular}{|c|c|c|c|c|c|c|c|c|c|}
\hline \multirow[t]{2}{*}{ Country } & \multicolumn{3}{|c|}{$\begin{array}{l}\% \text { of } 25-45 \text { year olds } \\
\text { who are employed }\end{array}$} & \multicolumn{3}{|c|}{$\begin{array}{c}\% \text { of } 25-45 \text { year olds } \\
\text { who have formal } \\
\text { employment }\end{array}$} & \multicolumn{3}{|c|}{$\begin{array}{l}\text { Average wage of } \\
\text { employed } 25-45 \text { age } \\
\text { group }\end{array}$} \\
\hline & $1990 \mathrm{~s}$ & $2000 \mathrm{~s}$ & $2010 \mathrm{~s}$ & $1990 \mathrm{~s}$ & $2000 \mathrm{~s}$ & $2010 \mathrm{~s}$ & $1990 \mathrm{~s}$ & $2000 \mathrm{~s}$ & $2010 \mathrm{~s}$ \\
\hline Argentina & $70 \%$ & $68 \%$ & $76 \%$ & $56 \%$ & $57 \%$ & $61 \%$ & 96 & 98.8 & 175.9 \\
\hline Bolivia & $70 \%$ & $78 \%$ & $82 \%$ & $41 \%$ & $41 \%$ & $41 \%$ & 95.8 & 101.5 & 91.6 \\
\hline Brasil & $72 \%$ & $72 \%$ & $77 \%$ & $55 \%$ & $54 \%$ & $61 \%$ & 97 & 98.7 & 94.6 \\
\hline Chile & $63 \%$ & $73 \%$ & $73 \%$ & $63 \%$ & $68 \%$ & $72 \%$ & 97.3 & 100.1 & 121.7 \\
\hline Colombia & $70 \%$ & $71 \%$ & $73 \%$ & & & $40 \%$ & 99.5 & 98.7 & 114.3 \\
\hline Costa Rica & $65 \%$ & $70 \%$ & $72 \%$ & $64 \%$ & $60 \%$ & $64 \%$ & 101.7 & 100.1 & 113.2 \\
\hline Dominican Republic & $78 \%$ & $76 \%$ & $75 \%$ & & $46 \%$ & $49 \%$ & 103.9 & 96.1 & 152.1 \\
\hline Ecuador & $70 \%$ & $71 \%$ & $73 \%$ & $45 \%$ & $44 \%$ & $45 \%$ & 91.1 & 105.6 & 124.1 \\
\hline El Salvador & $68 \%$ & $71 \%$ & $71 \%$ & $49 \%$ & $53 \%$ & $44 \%$ & 92.8 & 97.6 & 86.4 \\
\hline Guatemala & $64 \%$ & $69 \%$ & $72 \%$ & $47 \%$ & $55 \%$ & $55 \%$ & 92.8 & 98.9 & 90.9 \\
\hline Honduras & $61 \%$ & $69 \%$ & $72 \%$ & $50 \%$ & $48 \%$ & $51 \%$ & & & \\
\hline Mexico & $60 \%$ & $68 \%$ & $74 \%$ & $57 \%$ & $58 \%$ & $55 \%$ & 97.8 & 100.1 & 117.5 \\
\hline Nicaragua & $64 \%$ & $68 \%$ & $75 \%$ & $51 \%$ & $42 \%$ & $57 \%$ & 98.8 & 100.3 & 107 \\
\hline Panama & $74 \%$ & $73 \%$ & $76 \%$ & $68 \%$ & $65 \%$ & $67 \%$ & 103.1 & 101.5 & 99.6 \\
\hline Paraguay & $76 \%$ & $75 \%$ & $79 \%$ & $45 \%$ & $41 \%$ & $45 \%$ & 103.7 & 100 & 106.3 \\
\hline Peru & $66 \%$ & $68 \%$ & $70 \%$ & $60 \%$ & $37 \%$ & $42 \%$ & 108.3 & 99.5 & 110.8 \\
\hline Uruguay & $77 \%$ & $77 \%$ & $83 \%$ & $64 \%$ & $65 \%$ & $63 \%$ & 112 & 100.3 & 102.5 \\
\hline Venezuela & $68 \%$ & $70 \%$ & $74 \%$ & $61 \%$ & $46 \%$ & $49 \%$ & 133.2 & 101 & 75.2 \\
\hline Latin America & $69 \%$ & $72 \%$ & $75 \%$ & $55 \%$ & $52 \%$ & $53 \%$ & 101.5 & 99.9 & 110.8 \\
\hline
\end{tabular}

Source: Calculations from ECLAC indicators system (http://estadisticas.cepal.org/cepalstat).

Table A.9. Average returns to schooling in Latin America during 1990-2010

\begin{tabular}{lccccccc}
\hline & \multicolumn{2}{c}{ Returns to Secondary relative to Primary } & & \multicolumn{3}{c}{ Returns to Higher Educ. relative to Primary } \\
\cline { 2 - 3 } \cline { 7 - 8 } Country & $1990 \mathrm{~s}$ & 2000 & 2010 & & $1990 \mathrm{~s}$ & 2000 & 2010 \\
\hline Argentina & 0.66 & 1.58 & 1.37 & & 0.92 & 2.38 & 2.08 \\
Bolivia & 1.27 & 1.83 & 1.65 & & 2.1 & 2.23 & 2.05 \\
Brasil & 1.83 & 1.81 & 1.74 & & 2.71 & 2.73 & 2.82 \\
Chile & 1.81 & 1.93 & 1.42 & & 2.15 & 2.34 & 2.17 \\
Colombia & 2.3 & 2.69 & 2.86 & & 2.58 & 2.35 & 2.98 \\
Costa Rica & 1.89 & 2 & 1.96 & & 2.85 & 3.16 & 2.54 \\
\hline
\end{tabular}




\begin{tabular}{|c|c|c|c|c|c|c|}
\hline Ecuador & 2.57 & 2.05 & 1.67 & 2.77 & 2.27 & 2.61 \\
\hline El Salvador & 1.62 & 1.7 & 1.97 & 2.08 & 2.15 & 2.8 \\
\hline Guatemala & 1.98 & 2.25 & 1.56 & 2.3 & 2.8 & 2.45 \\
\hline Honduras & 2.06 & 1.78 & 1.76 & 2.45 & 2.94 & 2.36 \\
\hline México & 2.26 & 2.19 & 2.57 & 2.29 & 2.2 & 2.5 \\
\hline Nicaragua & 1.83 & 1.88 & 1.89 & 2.45 & 2.58 & 2.57 \\
\hline Panamá & 2.27 & 2.27 & 1.85 & 2.76 & 2.47 & 2.62 \\
\hline Paraguay & 1.82 & 1.69 & 1.54 & 1.88 & 2.47 & 2.23 \\
\hline Peru & 1.3 & 2.14 & 1.68 & 1.53 & 2.58 & 2.33 \\
\hline R. Dominicana & 1.77 & 1.79 & 1.75 & 2.63 & 2.68 & 2.59 \\
\hline Uruguay & 1.7 & 1.52 & 1.15 & 2.7 & 2.7 & 1.67 \\
\hline Venezuela & 1.7 & 1.7 & 1.94 & 2.46 & 2.63 & 2.75 \\
\hline Average LAC & 1.81 & 1.93 & 1.8 & 2.31 & 2.54 & 2.45 \\
\hline
\end{tabular}

Source: Author's calculations.

\section{Copyrights}

Copyright for this article is retained by the author(s), with first publication rights granted to the journal.

This is an open-access article distributed under the terms and conditions of the Creative Commons Attribution license (http://creativecommons.org/licenses/by/4.0/). 